\title{
Cannabidiol protects against hepatic ischemia/reperfusion injury by attenuating inflammatory signaling and response, oxidative/ nitrative stress, and cell death
}

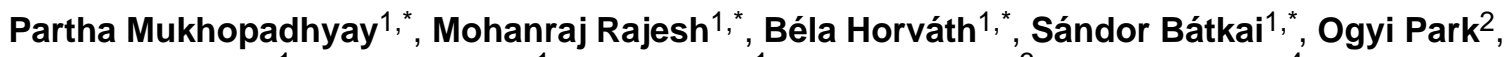 \\ Galin Tanashian ${ }^{1}$, Rachel Y Gao ${ }^{1}$, Vivek Patel ${ }^{1}$, David A. Wink ${ }^{3}$, Lucas Liaudet ${ }^{4}$, György \\ Haskó $^{5}$, Raphael Mechoulam ${ }^{6}$, and Pál Pacher ${ }^{1}$ \\ ${ }^{1}$ Laboratory of Physiologic Studies, National Institute on Alcohol Abuse and Alcoholism, National \\ Institutes of Health, Bethesda, Maryland, USA ${ }^{2}$ Laboratory of Liver Diseases, National Institute \\ on Alcohol Abuse and Alcoholism, National Institutes of Health, Bethesda, Maryland, USA ${ }^{3}$ \\ Radiation Biology Branch, NCI, National Institutes of Health, Bethesda, Maryland, USA 4 \\ Department of Intensive Care Medicine, University Hospital, Lausanne, Switzerland ${ }^{5}$ Department \\ of Surgery, University of Medicine and Dentistry of New Jersey-New Jersey Medical School, \\ Newark, New Jersey 07103, USA ${ }^{6}$ Department for Medicinal Chemistry and Natural Products, \\ Faculty of Medicine, Hebrew University of Jerusalem, Ein Kerem, Jerusalem, Israel
}

\begin{abstract}
Ischemia-reperfusion (I/R) is a pivotal mechanism of liver damage following liver transplantation or hepatic surgery. We have investigated the effects of cannabidiol(CBD), the non-psychotropic constituent of marijuana, in a mouse model of hepatic I/R injury. I/R triggered time-dependent increases/changes in markers of liver injury (serum transaminases), hepatic oxidative/nitrative stress (4-hydroxy-2-nonenal, nitrotyrosine content/staining, gp91phox and inducible nitric oxide synthase mRNA), mitochondrial dysfunction (decreased complex I activity), inflammation (tumor necrosis factor alpha (TNF- $\alpha$ ), cyclooxygenase 2 , macrophage inflammatory protein- $1 \alpha / 2$, intercellular adhesion molecule 1 mRNA levels, tissue neutrophil infiltration, nuclear factor kappa $B$ (NF-KB) activation), stress signaling (p38MAPK and JNK) and cell death (DNA fragmentation, PARP activity, and TUNEL). CBD significantly reduced the extent of liver inflammation, oxidative/nitrative stress and cell death, and also attenuated the bacterial endotoxin-triggered NF$\mathrm{KB}$ activation and TNF- $\alpha$ production in isolated Kupffer cells, likewise the adhesion molecules expression in primary human liver sinusoidal endothelial cells stimulated with TNF- $\alpha$, and attachment of human neutrophils to the activated endothelium. These protective effects were preserved in $\mathrm{CB}_{2}$ knockout mice and were not prevented by $\mathrm{CB}_{1 / 2}$ antagonists in vitro. Thus, $\mathrm{CBD}$ may represent a novel, protective strategy against I/R injury by attenuating key inflammatory pathways and oxidative/nitrative tissue injury, independent from classical $\mathrm{CB}_{1 / 2}$ receptors.
\end{abstract}

Corresponding Author: Pál Pacher M.D., Ph.D., F.A.P.S., F.A.H.A., Section on Oxidative Stress Tissue Injury, Laboratory of Physiological Studies, National Institutes of Health/NIAAA, 5625 Fishers Lane, MSC-9413, Bethesda, Maryland 20892-9413, USA. Phone: (301)443-4830; Fax: (301)480-0257; pacher@mail.nih.gov.

equally contributed

Disclosures: No conflict of interest to disclose.

Publisher's Disclaimer: This is a PDF file of an unedited manuscript that has been accepted for publication. As a service to our customers we are providing this early version of the manuscript. The manuscript will undergo copyediting, typesetting, and review of the resulting proof before it is published in its final citable form. Please note that during the production process errors may be discovered which could affect the content, and all legal disclaimers that apply to the journal pertain. 


\section{Keywords}

cannabinoids; oxidative stress; inflammation; ischemia-reperfusion

\section{Introduction}

Ischemia reperfusion (I/R) is the pivotal mechanism of tissue damage in pathological conditions such as stroke, myocardial infarction, vascular surgery, organ transplantation, and various forms of shock [1-4]. The destructive effects of I/R is triggered by the acute generation of reactive oxygen and nitrogen species following reoxygenation, which causes direct tissue injury and initiate a chain of deleterious cellular responses leading to inflammation, cell death, which eventually culminate in target organ failure [3-12].

Cannabidiol (CBD) is the most abundant non-psychotropic constituent of Cannabis sativa (marijuana) plant $[13,14]$. CBD has been reported to exert protective effects in multiple disease models $[13,15]$ and may alleviate pain and spasticity associated with multiple sclerosis in humans [16]. In contrast to the delta 9-tetrahydrocannabinol (THC; the most characterized active ingredient of marijuana) [14], CBD does not bind to classic cannabinoid $1\left(\mathrm{CB}_{1}\right)$ receptors $[17,18]$, which mediate the psychoactive and analgesic properties of marijuana and THC in the central nervous system. Furthermore, CBD is also devoid of potential to cause adverse cardiac effects mediated by cardiovascular $\mathrm{CB}_{1}$ receptors [19], which have recently been implicated in the pathophysiology of multiple cardiovascular diseases including heart failure, shock and atherosclerosis [19-21]. CBD is well tolerated without side effects when chronically administered to humans [22,23] and has been approved for the treatment of inflammation, pain and spasticity associated with multiple sclerosis since 2005 in Canada [16,19]. Previous studies have suggested multiple mechanisms to explain the beneficial effects of CBD in preclinical models of inflammation and tissue injury [13], including its potent antioxidant [24] and anti-inflammatory [15,25] properties.

In this study we have investigated the effects of CBD using an in vivo well characterized mouse model of hepatic I/R injury [26-29] (in which the initial damage is inflicted by the generation of reactive oxygen and nitrogen species followed by acute and chronic inflammatory response) on the course of liver damage, oxidative/nitrative stress, acute and chronic inflammatory response, signaling and cell death. We have also studied the effects of CBD on inflammatory response and signaling of isolated mouse Kupffer cells (key resident inflammatory cells of the liver) and on primary human sinusoidal endothelial cell activation and attachment of neutrophils to the activated endothelium. Because it has been demonstrated that $\mathrm{CBD}$ displayed unexpectedly high potency as an inverse agonist at cannabinoid $2\left(\mathrm{CB}_{2}\right)$ receptors in vitro [30], but in vivo it behaved rather as $\mathrm{CB}_{2}$ receptor agonist in an obesity model [31], coupled with the known protective effects of $\mathrm{CB}_{2}$ receptors on endothelial, inflammatory and perhaps some parenchyma cells against hepatic $[27,28]$ and other forms of $\mathrm{I} / \mathrm{R}$ injury [32-35], we also explored the plausible role of $\mathrm{CB}_{2}$ receptors in the effects of $\mathrm{CBD}$ on hepatic $\mathrm{I} / \mathrm{R}$ injury using $\mathrm{CB}_{2}$ receptor knockout mice or pharmacological tools. Our findings underscore the potential of CBD for the prevention/ treatment of hepatic and perhaps other forms of ischemic-reperfusion injury and inflammatory diseases. 


\section{Materials and methods}

\section{Hepatic ischemia reperfusion}

Protocols involving the use of animals were approved by the Institutional Animal Care and Use Committees and were performed in line with the National Institutes of Health (NIH) guidelines for the care and use of laboratory animals. Male C57BL/6J mice (25-30g) were anesthetized with pentobarbital ( $65 \mathrm{mg} / \mathrm{kg}$ i.p.). A midline laparotomy incision was performed to expose the liver. The hepatic artery and the portal vein were clamped using microaneurysm clamps. This model results in a segmental (70\%) hepatic ischemia as described [26-29]. Briefly, the liver was exposed by midline laparotomy and the hepatic artery and the portal vein were clamped using an atraumatic micro-serrefine. This method of partial ischemia prevents mesenteric venous congestion by allowing portal decompression throughout the right and caudate lobes of the liver. The duration of hepatic ischemia was 60 $\mathrm{min}$, after which the vascular clips were removed and liver was reperfused for $2 \mathrm{~h}, 6 \mathrm{~h}$ or 24 $\mathrm{h}$, as indicated. Sham surgeries were identical except that hepatic blood vessels were not clamped with a micro serrefine. The liver was kept moist at $37^{\circ} \mathrm{C}$ with gauze soaked in $0.9 \%$ saline. Body temperature was maintained at $37^{\circ} \mathrm{C}$ using a thermoregulatory heating blanket and by monitoring body temperature with a rectal temperature probe. Treatment with 3 and $10 \mathrm{mg} / \mathrm{kg}$ cannabidiol (CBD) or vehicle intraperitoneally (i.p.), started $2 \mathrm{~h}$ before IR or given as indicated in the text. Similar procedures were carried out in $\mathrm{CB}_{2}{ }^{-1-}$ mice on C57BL/6J background [27,36]. After reperfusion, blood was collected and liver samples were removed and snap-frozen in liquid nitrogen for determining biochemical parameters or fixed in $4 \%$ buffered formalin for histopathological evaluation [27].

\section{Drugs}

CBD was isolated as described [37]. All drugs were dissolved in vehicle solution (one drop of Tween-80 in $3 \mathrm{ml} 2.5 \%$ DMSO in saline) and injected i.p. $60 \mathrm{~min}$ prior the occlusion of the hepatic artery and the portal vein. In a separate set of experiments, CBD ( 3 and/or 10 $\mathrm{mg} / \mathrm{kg}$ ) or vehicle was injected into the femoral vein right before the reocclusion or $90 \mathrm{mins}$ after. Vehicle solution was used in control experiments. For cell culture experiments, all lipid-soluble drugs were dissolved in DMSO. All chemicals were from Sigma Chemical Co. (St. Louis, MO, USA), except where it was mentioned.

\section{Serum AST and ALT levels}

The activities of aspartate amino-transferase (AST) and alanine amino-transferase (ALT), indicators of liver damage, were measured in serum samples using a clinical chemistry analyzer system (VetTest 8008, IDEXX laboratories, Westbrook, ME) [27-29].

\section{Histological examination of liver sections}

Liver samples were fixed in $4 \%$ buffered formalin. After embedding and cutting $4 \mu \mathrm{m}$ slices, all sections were stained with hematoxylin/eosin (HE). For myeloperoxidase (MPO) and nitrotyrosine staning slides were deparaffinized, and hydrated in descending gradations of ethanol, followed by antigen retrieval procedure. Next, sections were incubated in $0.3 \%$ $\mathrm{H}_{2} \mathrm{O}_{2}$ in PBS to block endogenous peroxidase activity. The sections were then incubated with anti-MPO (Biocare Medical, Concord, CA) or anti-nitrotyrosine (1:200 dilution; Cayman Chemical, Ann Arbor, MI, USA) antibodies overnight at $4^{\circ} \mathrm{C}$ in a moist chamber. Biotinylated secondary antibodies and $\mathrm{ABC}$ reagent were added as per the kit's instructions (Vector Laboratories, Burlingame, CA, USA). Color development was induced by incubation with a DAB kit (Vector Laboratories) for 3-5 min, and the sections were counterstained with nuclear fast red as described $[27,28,36]$. Finally, the sections were dehydrated in ethanol and cleared in xylene and mounted. The specific staining was visualized and 
images were acquired using microscope IX-81 with 20X, 40X and 100x objectives

(Olympus, Center Valley, PA). Histological evaluation was performed in a blinded manner.

\section{Hepatic TUNEL immuno-histochemistry}

Paraffin sections were dewaxed and in situ detection of apoptosis in the hepatic tissues was performed by terminal deoxynucleotodyltransferase mediated nick-end labeling (TUNEL) assay as per the instruction provided with the kit (Roche Diagnostics, Indianapolis, IN). Nucleus was labeled with Hoechst 33242 and the TUNEL positive cells were observed using confocal microscopy. Digital images were taken by a LSM Pascal confocal microscope (Carl Zeiss, Thornwood, NY) at a resolution of 2,048 $\times 2,048$ pixels. Images were captured using 40X objectives and the optical section was $<1 \mu \mathrm{m}$. The morphometric examination was performed by two independent, blinded investigators. The number of apoptotic cells in each section was calculated by counting the number of TUNEL-positive apoptotic cells in 10-12 of 40X fields/per condition from at least 3-5 independent samples/group [36].

\section{Hepatic DNA fragmentation ELISA}

The quantitative determinations of cytoplasmic histone-associated-DNA-fragmentation (mono and oligonucleosomes) due to in vivo cell death were measured using ELISA kit (Roche Diagnostics GmbH, Indianapolis, IN) [38,39].

\section{Determination of hepatic poly(ADP-ribose) polymerase (PARP) activity}

Hepatic PARP activity was assayed using a colorimetric kit according to manufacturer's protocol (Trevigen, Gaithersburg, MD) as described [40].

\section{Real-Time PCR Analyses of mRNA}

Total RNA was isolated from liver homogenate using TRIzol reagents (Invitrogen, Carlsbad, CA) according to manufacturer's instructions. The isolated RNA was treated with RNasefree DNase (Ambion, Austin, TX) to remove traces of genomic DNA contamination. One microgram of total RNA was reverse-transcribed to cDNA using the SuperScript II (Invitrogen, Carlsbad, CA). The target gene expression was quantified with Power SYBER Green PCR Master Mix using an ABI HT7900 real-time PCR instrument (Applied Biosystems, Foster City, CA). Each amplified sample in all wells was analyzed for homogeneity using dissociation curve analysis. After denaturation at $95^{\circ} \mathrm{C}$ for $2 \mathrm{~min}, 40$ cycles were performed at $95^{\circ} \mathrm{C}$ for $10 \mathrm{~s}$ and at $60^{\circ} \mathrm{C}$ for $30 \mathrm{~s}$. Relative quantification was calculated using the comparative CT method (2- $\Delta \Delta \mathrm{Ct}$ method: $\Delta \Delta \mathrm{Ct}=\Delta \mathrm{Ct}$ sample $-\Delta \mathrm{Ct}$ reference). Lower $\Delta \mathrm{CT}$ values and lower $\Delta \Delta \mathrm{CT}$ reflect a relatively higher amount of gene transcript. Statistical analyses were carried out for at least six to 15 replicate experimental samples in each set.

Primers used were as follows:

TNF- $\alpha$ 5'-AAGCCTGTAGCCCACGTCGTA-3' and 5'AGGTACAACCCATCGGCTGG-3';

MIP1- $\alpha 5^{\prime}$-TGCCCTTGCTGTTCTTCTCTG-3' and 5'CAACGATGAATTGGCGTGG-3';

MIP2 5'-AGTGAACTGCGCTGTCAATGC-3' and 5'AGGCAAACTTTTTGACCGCC-3';

ICAM1 5'-AACTTTTCAGCTCCGGTCCTG-3' and 5'TCAGTGTGAATTGGACCTGCG-3'; 
NOX2 5'-GACCATTGCAAGTGAACACCC-3' and 5'AAATGAAGTGGACTCCACGCG3';

iNOS 5'-ATTCACAGCTCATCCGGTACG-3' and 5'GGATCTTGACCATCAGCTTGC-3';

COX2 5'-GTGTATCCCCCCACAGTCAAA-3' and 5'ACACTCTGTTGTGCTCCCGAA-3';

and actin, 5'-TGCACCACCAACTGCTTAG-3' and 5'GGATGCAGGGATGATGTTC-3'

\section{Hepatic 4-hydroxynonenal (4-HNE) content}

Lipid peroxides are unstable indicators of oxidative stress in cells that decompose to form more complex and reactive compounds such as 4-hydroxynonenal (HNE), which has been shown to be capable of binding to proteins and forming stable HNE adducts. There is also emerging recent evidence implicating HNE in various key signaling processes [41,42]. HNE in the hepatic tissues was determined using a kit (Cell Biolabs, San Diego, CA). In brief, BSA or hepatic tissue extracts $(10 \mu \mathrm{g} / \mathrm{mL})$ are adsorbed onto a 96-well plate for $12 \mathrm{hrs}$ at $4^{\circ} \mathrm{C}$. HNE adducts present in the sample or standard are probed with anti-HNE antibody, followed by an HRP conjugated secondary antibody. The HNE-protein adducts content in an unknown sample is determined by comparing with a standard curve $[43,44]$.

\section{Isolation and stimulation of hepatic Kupffer cells}

Livers were perfused in the deeply anaesthetized mouse and the livers were excised for isolation of Kupffer cells [27]. Hepatic cellular contents were released from the stroma by digestion with the perfusion medium (hepatocyte wash media) containing Collagenase type 1 (Sigma, St. Louis, MO) and $2 \%$ Penicillin and Streptomycin (Invitrogen, Carlsbad, CA). Kupffer cells were isolated using Optiprep gradient. Kupffer cell fraction was aspirated and washed 2 times with RPMI 1640 medium. Homogenous Kupffer cells population was obtained by using negative selection (anti-CD146) LS column according to manufacturer's instruction (Miltenyi Biotec, Auburn, CA). After additional washes, Kupffer cells were plated on to 96 well or 6 well plates in RPMI 1640 media containing 10\% FBS and Penicillin-Streptomycin for overnight in $\mathrm{CO}_{2}$ incubator at $37^{\circ} \mathrm{C}$ and $5 \% \mathrm{CO}_{2}$. Cells were maintained for 2 hours with RPMI 1640 medium containing FBS (2\%). CBD at indicated concentrations were added $1 \mathrm{~h}$ prior to LPS treatment. Cells were treated for 6 hours with LPS (Escherichia Coli O127:BB catalogue \# L3129, Sigma Chemicals, St Louis, MO). After the end of treatments, culture supernatants were removed and snap frozen in liquid nitrogen and assayed for the TNF- $\alpha$ concentrations with the use of ELISA kit (Mouse TNF$\alpha$; catalogue \# SMTA00; R\&D systems, Minneapolis, MN).

\section{Immunoblot analyses}

Liver tissues were homogenized in mammalian tissue protein extraction reagent (TPER, Pierce, Rockford, IL) supplemented with protease and phosphatase inhibitors (Roche Diagnostics, Indianapolis, IN). Kupffer cells were lyzed in RIPA buffer supplemented with protease and phosphatase inhibitors. Blots were probed with either rabbit p38 MAPK, phospho p38 (Thr 180/Tyr 182) MAPK, IкB- $\alpha$, phospho (Ser 32/36) IкB- $\alpha$, SAPK/JNK, phospho SAPK/JNK (Thr183/Tyr185), (Cell Signaling Technology, Beverly, MA) and were used at 1:1000 dilution and incubated overnight at $4^{\circ} \mathrm{C}$. After subsequent washing with PBST, the membranes were probed with appropriate secondary antibodies conjugated with HRP (Pierce, Rockford, IL) and incubated $1 \mathrm{~h}$ at RT. Then the membranes were developed using Super Signal-West Pico Substrate chemiluminescence detection kit (Pierce, Rockford, 
IL). To confirm uniform loading, membranes were stripped and re-probed with $\beta$-actin (Chemicon, Ramona, CA).

\section{Measurement of NF-kB activation by gel shift assay}

The NF- $\kappa \mathrm{B}$ activation in the liver tissue samples was performed using the reagents and the accompanying protocols from Panomics, Inc. (Fremont, CA). In brief, the nuclear extracts isolated by NE-PER kit (Pierce, Rockford, IL) from liver were incubated with biotin-labeled transcription factor probe, and then the protein/DNA complexes were separated on a nondenaturing polyacrylamide gel. The gel was transferred to a Biodyne A nylon membrane (Pierce, Rockford, IL) and detected using streptavidin-HRP and chemiluminescent substrate. The shifted bands corresponding to the protein/DNA complexes were identified relative to the unbound dsDNA. The illuminated images were visualized in VersaDoc MP4000 imaging system (BioRad, Hercules, CA).

\section{Determination of mitochondrial complex I activity}

Microplate assay kit (MitoSciences Inc., Eugene, OR) were used to determine the activity of oxidative phosphorylation Complex I according to the manufacturer's instructions. The Complex-I enzyme was immunocaptured within the wells of the microplate and activity was determined colorimetrically by following the oxidation of NADH to NAD+ and the simultaneous reduction of a dye which leads to the absorbance change at $450 \mathrm{~nm}$. Complex activity was expressed as percent activity compared to the liver samples of the vehicle treated mice.

\section{Cell Surface ICAM-1 and VCAM-1 Expression Assay}

Cell surface expression of ICAM-1 and VCAM-1 in the human liver sinusoidal endothelial cells (HLSEC) was measured by in situ ELISA as described $[27,28,45]\}$. In brief, HLSEC cells were grown in 96-well plates. After treatments as described in figure, in situ ELISA was performed with anti-mouse ICAM-1 or VCAM-1 monoclonal antibodies (1:1,500 dilution; R\&D Systems) and by measuring the absorbance colorimetrically at $450 \mathrm{~nm}$ using the horseradish peroxidase-3,3',5,5'-tetramethylbenzidine developing system (Sigma, St. Louis, MO). Each treatment was performed in triplicate, and the experiments were repeated three times.

\section{(PMN)-endothelial cell adhesion}

Neutrophil adhesion to endothelial cells was performed as described [27] with modifications in the protocol. In brief, HLSECs were grown to confluence in 24-well plates and treated with TNF $\alpha$ and cannabidiol as described in the text. Then, PMN were labeled with $2.5 \mu \mathrm{M}$ Calcein-AM (Molecular Probes-Invitrogen, Carlsbad, CA) for $1 \mathrm{~h}$ at $37^{\circ} \mathrm{C}$ in RPMI 1640 containing $1 \%$ FBS. HLSECs were washed twice with HLSECs basal medium and covered with $400 \mu \mathrm{l}$ of HLSECs basal medium. Then $5 \times 10^{4} / 100 \mu \mathrm{l}$ labeled PMN cells were added to HLSECs and incubated for $1 \mathrm{~h}$ at $37^{\circ} \mathrm{C}$. After incubation, the monolayer was carefully washed with PBS to remove the unbound PMN. The adherent PMNs were documented by Olympus IX 81 fluorescent microscope using 20X objective (Olympus America, Center Vally, PA). Three fields were captured in all experimental conditions. Individual treatments were performed in duplicate, and the entire set of experiments was repeated twice. The number of adherent PMN cells were counted using NIH Image $\mathbf{J}$ software and the values were expressed as PMN adhered/field.

\section{Hepatic protein nitrotyrosine (NT) content determination}

Nitrotyrosine formation was initially considered as a specific marker of in vivo peroxynitrite generation, but now it is rather used as a collective index of nitrative stress, because other 
pathways have also been proposed to be involved in its formation (e.g., myeloperoxidase in certain inflammatory conditions) [46-48]. Hepatic nitrotyrosine content was determined by nitrotyrosine ELISA according to the protocol supplied with the kit (Hycult Biotechnology, Cell Sciences, Canton, MA) as described [40,44].

\section{Statistical analysis}

Results are expressed as mean \pm SEM. Statistical significance among groups was determined by one-way ANOVA followed by Newman-Keuls post hoc analysis using GraphPad Prism 5 software (San Diego, CA). Probability values of $P<0.05$ were considered significant.

\section{Results}

\section{Cannabidiol attenuates markers of hepatic I/R injury (ALT, AST)}

For assessments of hepatocellular damage of the post-ischemic liver, the serum transaminases (AST and ALT) activities were measured. After 1 hour of ischemia and a subsequent 2 or 6 hours of reperfusion (I/R $2 \mathrm{~h}$ or I/R 6h), a dramatic increase in liver enzyme activities were observed in vehicle-treated C57B16J mice as compared with shamoperated controls (Figure 1A, B). Pretreatment with CBD (3-10 mg/kg, CBD 3 and 10 respectively) 2 hours before the induction of the ischemia dose-dependently attenuated the serum transaminase elevations at 2 and 6 hours of reperfusion compared to vehicle (ALT level decreased by $\sim 11 \%$ with CBD $3 \mathrm{mg} / \mathrm{kg}$ and by $\sim 68 \%$ with CBD $10 \mathrm{mg} / \mathrm{kg}$ whereas AST decreased by $3 \%$ and $48 \%$ respectively at $2 \mathrm{~h}$ reperfusion. ALT level decreased by $84 \%$ with CBD $3 \mathrm{mg} / \mathrm{kg}$ and by $70 \%$ with CBD $10 \mathrm{mg} / \mathrm{kg}$, whereas AST decreased by $73 \%$ and $68 \%$, respectively at 6 hours of reperfusion (Figure 1). Furthermore, pre-treatment with CBD $3 \mathrm{mg} / \mathrm{kg}$ of $\mathrm{CB}_{2}{ }^{-1-}$ knockout mice, which had significantly ( $\left.~ 53-67 \%\right)$ increased damage at 6 hours of reperfusion (this is the time of the peak serum ALT/AST elevations/ injury following induction of the ischemia), resulted in similar degree of protection seen in their wild type littermates (reduction of serum ALT/AST by $~ 81 \%$ and $77 \%$, respectively), excluding any significant role of $\mathrm{CB}_{2}$ receptors in the beneficial effects of $\mathrm{CBD}$. $\mathrm{CBD}$ alone had no effects on ALT and AST levels compared to the vehicle-treated group. CBD treatment given right after the induction of the ischemia (Figure 2A) or at 90 minutes of reperfusion (Figure 2B) was still able to attenuate, though to a lesser extent, the hepatic injury measured at 6 hours of reperfusion.

\section{Cannabidiol improves I/R-induced histological damage}

I/R induced marked coagulation necrosis after 24 hours of reperfusion (lighter areas, with marked inflammatory cell infiltration), which was dramatically reduced and became more focal in CBD treated mice. CBD treatment or vehicle alone had no effect on the histopathology of the liver (Figure 3).

\section{Cannabidiol attenuates I/R-induced hepatic cell death}

TUNEL staining of liver sections at 24 hours of reperfusion showed significant increase in apoptotic bodies, which was attenuated by CBD $(10 \mathrm{mg} / \mathrm{kg})$ pretreatment of mice (Figure $4 \mathrm{~A})$. The quantification of cell death demonstrated $\sim 10$ fold increase in apoptotic cells after 24 hours of reperfusion, which was attenuated by $\sim 70 \%$ with CBD pretreatment. DNA fragmentation (Figure 4B) and PARP activity (Figure 4C) showed time-dependent increases in liver homogenates following 2, 6 and 24 hours of reperfusion (DNA fragmentation increased by $\sim 2.4, \sim 4.7$ and $\sim 10.9$ folds at 2,6 and 24 hours of reperfusion, respectively, while PARP activity by $\sim 3.7, \sim 3.8$ and $\sim 2.8$ folds), which were markedly attenuated by CBD $(10 \mathrm{mg} / \mathrm{kg}$ ) pretreatment (DNA fragmentation decreased by $33 \%, 49 \%$ and $56 \%$, while PARP activity by $\sim 44 \%, 45 \%$ and $34 \%$, respectively). 
Cannabidiol attenuates I/R-induced hepatic pro-inflammatory chemokine, cytokines and adhesion molecule expression

I/R greatly increased the expression of mRNA of chemokines MIP-1 $\alpha$ (CCL3) and MIP-2 (CXCL2) in liver tissue as documented by Real-time PCR, which was attenuated by $10 \mathrm{mg}$ / $\mathrm{kg}$ CBD (Figure 5). Hepatic MIP-1 $\alpha$ mRNA increased to the highest level at 2 hours of reperfusion (by $\sim 25.7$ folds) and gradually decreased by 24 hours of reperfusion to the less than half. CBD treatment decreased hepatic peak MIP-1 $\alpha$ mRNA level at 2 hours of reperfusion by $66 \%$ (Figure 5A). MIP2 increased to the peak level at 2 hours of reperfusion ( $\sim 31.8$ fold increase) and gradually decreased by 24 hours of reperfusion. CBD treatment attenuated the increase of MIP2 mRNA level ( 7.3 fold compared to control) at 2 hours of reperfusion, as well as markedly attenuated I/R values at 6 and 24 hours of reperfusion (Figure 5B).

Real-time PCR analyses of adhesion molecule ICAM- 1 and cytokine TNF- $1 \alpha$ mRNA demonstrated markedly increased expression in liver tissue after I/R, peaking at 2 hours of reperfusion ( 14 and 40 folds increases, respectively) and gradually declining thereafter (Figure 6 A, B). CBD pretreatment decreased the I/R-induced increased ICAM- 1 and TNF- $1 \alpha$ mRNA expression to $\sim 50 \%$, and $25 \%$ of their initial values at 2 hours of reperfusion, respectively. CBD also markedly attenuated these values at 6 and 24 hours following reperfusion (Figure $6 \mathrm{~A}, \mathrm{~B}$ ).

\section{Cannabidiol attenuates I/R-induced marked neutrophil infiltration}

Neutrophils are important mediator of the delayed tissue injury following I/R. An indicator of neutrophil infiltration is the myeloperoxidase activity (MPO). In sham-operated wild-type mice, or in mice following 2 and 6 hours of reperfusion (not shown) the liver MPO staining was barely detectable, because infiltrating inflammatory cells were not yet present (Figure 7). In contrast, following 24 hours of reperfusion there was marked increase in infiltrating MPO positive immune cells, which was largely attenuated by CBD.

\section{Cannabidiol treatment attenuates I/R-induced hepatic nuclear factor-kB activation}

As shown in Figure 8A, gel shift assay confirmed the hepatic NF- $\mathrm{BB}$ activation in $\mathrm{I} / \mathrm{R}$. The CBD treatment attenuated the p65NF- $\mathrm{kB}$ nuclear translocation (Figure 8A).

\section{Cannabidiol attenuates I/R-induced p38 MAPK and JNK activation}

There was marked increase in the p38MAPK and c-Jun N-terminal kinase (JNK) activation in I/R liver tissue of mice at $2 \mathrm{~h}$ and $6 \mathrm{~h}$ following I/R injury, and CBD pretreatment at 10 $\mathrm{mg} / \mathrm{kg}$ attenuates these increases (Figure $8 \mathrm{~B}$ ).

\section{Cannabidiol decreases I/R-induced increased oxidative stress and attenuates I/R-induced decreased mitochondrial complex I activity}

The rate of lipid peroxidation was negligible in sham-operated mouse livers, as indicated by the low levels of HNE adducts. Hepatic HNE adducts increased time dependently to $\sim 3,4$ and 6.4 folds at 2, 6 and 24 hours of reperfusion, which were significantly attenuated by CBD $(10 \mathrm{mg} / \mathrm{kg}$ ) pretreatment to $\sim 2,1.9$ and 2.9 folds increases (compared to sham), respectively (Figure 9A). Mitochondrial complex I activity was decreased by $63 \%, 45 \%$ and $39 \%$ at 2, 6 and 24 hours of reperfusion, respectively, indicating dysfunction (Figure 9B). Pretreatment with CBD at $10 \mathrm{mg} / \mathrm{kg}$ restored the I/R-induced decrease in mitochondrial complex I activity at all time points of the reperfusion studied to normal level. The expression of the isoform of the superoxide generating NADPH oxidase enzyme, the gp91phox (NOX2), was also gradually increased to the peak level at 24 hours of reperfusion ( $\sim 5.1$ fold increase). CBD treatment markedly decreased I/R-induced peak in gp91phox 
level to $\sim 2.2$ fold at 24 hours of reperfusion ( $\sim 56 \%$ decrease), as well as attenuated I/R values at 6 hours of reperfusion (Figure $9 \mathrm{C}$ ).

\section{Cannabidiol attenuates I/R-induced hepatic iNOS, cyclooxygenase 2 (COX2) expressions and nitrotyrosine content}

Cyclooxygenase 2 (COX2) expression gradually increased at 2 ( 3.1 fold increase), 6 ( 5.4 fold increase) and 24 hours of reperfusion ( 9.8 fold increase). CBD treatment decreased I/ R-induced hepatic COX2 mRNA increases by $22 \%, 57 \%$ and 53\% at 2, 6 and 24 hours of reperfusion, respectively (Figure 10A).

$\mathrm{I} / \mathrm{R}$ increased the expression of mRNA of iNOS (NOS2) in liver tissues as documented by Real-time PCR, which was attenuated by $10 \mathrm{mg} / \mathrm{kg}$ CBD (Figure 10B). Hepatic iNOS mRNA gradually increased to the highest level at 24 hours of reperfusion $(\sim 5.4$ folds increase). CBD treatment attenuated hepatic I/R-induced iNOS mRNA levels at 6 and 24 hours of reperfusion by more than 50\% (Figure 10B).

Nitrotyrosine modification of protein, a marker for peroxynitrite formation and/or nitrative stress, increased to $\sim 2.2,4.5$ and 7.1 folds at 2, 6 and 24 hours of reperfusion, and was attenuated by CBD pretreatment at $10 \mathrm{mg} / \mathrm{kg}$ by 20,33 and $50 \%$, respectively (Figure 10C). $\mathrm{I} / \mathrm{R}$ also induced time-dependent marked increases in liver nitrotyrosine staining (Figure 11), while livers of sham operated animals were negative. Strong nitrotyrosine staining was present in endothelial cells, hepatocytes around the vessels in the damaged areas, as well as in the inflammatory infiltrate (neutrophil granulocytes, macrophages and Kupffer cells). CBD markedly attenuate the I/R-induced nitrotyrosine formation.

\section{CBD attenuates the endotoxin induced NFKB activation and TNF- $\alpha$ production in isolated mouse Kupffer cells}

Kupffer cells were isolated from mice as described in the Methods section, and then treated with bacterial lipopolysaccharide (LPS, $100 \mathrm{ng} / \mathrm{ml}$ ) in the presence or absence of CBD. As shown in Figure 12, LPS treatment augmented NFKB activation characterized by increased degradation and phosphorylation of I $\mathrm{B} \alpha$, which was suppressed by treated with CBD. LPS treatment drastically enhanced TNF- $\alpha$ production in the Kupffer cells, which was attenuated in a dose-dependent manner by CBD.

\section{CBD attenuates the TNF- $\alpha$-induced adhesion molecules expression and polymorphonuclear cells (PMN) adhesion to human sinusoidal endothelial cells (HLSEC)}

Treatment of HLSEC cells with TNF- $\alpha$ for 6 hours markedly enhanced the production of adhesion molecules such as ICAM-1 and VCAM-1 (Figure 13) and PMN adhesion (Figure 14). This was mitigated when cells were treated with CBD. To rule out the potential role of cannabinoid receptors in mediating CBD's effects, specific cannabinoid receptor inverse agonists/antagonists such as SR141716 (SR1 for $\mathrm{CB}_{1}$ receptor) and SR144528 (SR2 for $\mathrm{CB}_{2}$ receptor) were used. Interestingly, when HLSECs were treated with TNF- $\alpha$, in the presence of SR1, there was slight reduction in the adhesion molecule expression and PMN adhesion, while SR2 had only a small effect on VCAM-1 but not ICAM-1 or PMN adhesion. More importantly, CBD alone had greater anti-inflammatory effect in endothelial cells than SR1 or SR2, and this protection was not reversed by either SR1 or SR2 (it was rather additive with SR1), suggesting that $\mathrm{CB}_{1 / 2}$ receptors were not involved in mediating these effects. The beneficial effect of SR1 could be attributed to its known anti-inflammatory action [21]. 


\section{Discussion}

Hepatic I/R injury is a major clinical problem implicated in the liver failure associated with liver transplantation, hepatic surgery and circulatory shock, with unfortunately only limited therapeutic options. Cannabidiol, is a nonpsychotropic component of marijuana, which has been shown to exert antioxidant and anti-inflammatory effects both in vitro and in various preclinical models of neurodegeneration and inflammatory disorders, independent from conventional $\mathrm{CB}_{1}$ and $\mathrm{CB}_{2}$ receptors (reviewed in $[13,15]$ ). In the present study, we demonstrate that $\mathrm{CBD}$ exerts protective effect against liver I/R reperfusion damage by attenuating major pro-inflammatory and stress signaling pathways, as well as oxidative/ nitrative stress and cell death.

Initially, the destructive effects of $\mathrm{I} / \mathrm{R}$ is inflicted by the generation of superoxide and other forms of reactive oxygen species (ROS) following reoxygenation during reperfusion from the activation of various sources (e.g. xathine oxidoreductases $[49,50])$. This also leads to early impairment of the activities of the enzymes of the mitochondrial respiratory chain, mitochondrial dysfunction, allowing more ROS to leak out of the respiratory chain $[29,50]$. Consistently with previous studies demonstrating mitochondrial dysfunction in various forms of I/R [29,51,52], we found marked depression of mitochondrial complex I activity in the livers exposed to ischemia followed by reperfusion. This decreased complex I activity was most pronounced 2 hours following ischemia, but also persisted at 6 and 24 hours of reperfusion. In agreement with previous studies establishing that NADPH oxidase-derived superoxide (particularly gp91phox/NOX2-derived (gp91phox is abundantly present in various inflammatory cells including neutrophil granulocytes)), plays an important role in the development of hepatic I/R-induced injury $[4,11,12,26]$, we also found significantly increased expression of mRNA of gp91phox at 6 and 24 hours of reperfusion. The peak increase in gp91phox mRNA expression occurred 24 hours following the ischemic insult coinciding with the marked inflammatory cell infiltration in damaged livers. However, the absence of significantly increased gp91phox mRNA expression 2 hours following ischemia, coupled with markedly depressed mitochondrial complex I activity, support the view that at early stage of reperfusion injury mitochondria play important role in reactive oxygen species (ROS) generation.

The increased superoxide and $\mathrm{NO}$ generation during early hepatic reperfusion (the latter being most likely derived from increased iNOS induction) favors the formation of the potent oxidant peroxynitrite [53] via a diffusion limited reaction of superoxide with nitric oxide (NO) [54], further impairing mitochondrial [55] and cellular functions and increasing ROS generation $[7,29,50]$. Consistently with several recent studies demonstrating markedly enhanced iNOS gene/protein expressions during hepatic I/R [56-60], we found significant time-dependent increases in the liver iNOS mRNA expression at 2, 6 and 24 hours of reperfusion, peaking at 24 hours when the massive inflammatory cell infiltration occurred. There was also significant increase in hepatic nitrotyrosine (NT) content as early as at 2 hours of reperfusion, with further increase at 6 hours and dramatic enhancement at 24 hours of reperfusion. While nitrotyrosine has been considered a marker of peroxynitrite formation previously, there is some evidence that heme-protein peroxidase activity, in particular neutrophil-derived myeloperoxidase (MPO), may significantly contribute to nitrotyrosine formation in vivo via the oxidation of nitrite to nitrogen dioxide under certain inflammatory conditions [46,47], therefore it is rather used as a collective index of nitrative sress [3]. Since the neutrophil recruitment is known to occur in this hepatic I/R model predominantly from 6 hours of reperfusion (peaking between 12-24 hours), it is not very likely that the latter mechanism was significantly involved in the increased hepatic nitrotyrosine content/ staining observed at 2 and 6 hours of reperfusion compared to sham operated animals, however it may contribute to the additional elevation observed at 24 hours, at a time when 
there is a profound increase in the MPO positive infiltrating neutrophils. This is also supported by our results clearly demonstrating absence of infiltrating inflammatory cells (including MPO positive cells) at 2 and 6 hours of reperfusion in liver tissues. Furthermore, at earlier time points of reperfusion ( 2 and 6 hours) the NT staining is clearly localized in endothelial cells and perivascular hepatocytes which are the primary targets of I/R-induced injury (the staining being stronger at 6 hours of reperfusion when gp91phox and iNOS mRNA expressions are also elevated). At 24 hours of reperfusion we observed further dramatic enhancement of hepatic NT content/staining in endothelial cells and perivascular hepatocytes in the damaged areas, as well as in infiltrating (largely MPO positive) inflammatory cells in the necrotic areas. Importantly, the time-dependent increases in hepatic NT content/staining paralleled with increased expressions of superoxide generating gp91phox and iNOS, as well as with increased hepatic HNE adduct levels (marker of lipid peroxidation/oxidative stress $[41,42])$. Thus, it is very likely that the above described increased NT content/staining during reperfusion originates, at least in part, from increased peroxynitrite generation. Importantly, NO which is readily diffusible at a distance of several cells, irrespective of its source can rapidly react with superoxide (even produced in neighboring cells) to form peroxynitrite, resulting in decreased NO bioavailability with consequent loss of its protective effects [3]. It should also be noted that under various proinflammatory conditions both eNOS and iNOS may also be uncoupled and generate additional ROS aggravating the tissue damage [3]. Increasing evidence suggests that peroxynitrite during I/R injury may modulates/trigger various key stress signaling (e.g. p38 MAPK, JNK), pro-inflammatory (e.g. nuclear factor kappa B (NF-KB)) and cell death signaling pathways [3,61-64], promoting cell death (both apoptotic and necrotic).

Indeed, sustained ROS/RNS generation during hepatic reperfusion activates important stress signaling (e.g. p38MAPK, JNK) [65] and pro-inflammatory pathways (e.g. NF-KB [4,26,57,65-67], COX-2 [68,69]) in various cell types, in turn rmodulating/regulating important inflammatory and cell death processes. In agreement with these observations, we demonstrate time-dependent activation of these pathways at 2, 6 and/or 24 hours of reperfusion in the liver. After a more prolonged period of reperfusion, increased amounts of pro-inflammatory chemokines and cytokines are produced from activated Kupffer cells (resident macrophages of the liver) and endothelium leading to the priming and recruitment of neutrophils and other inflammatory cells, into the liver vasculature upon reperfusion, attachment to the activated endothelium and consequent activation resulting in further ROS/ RNS generation and release of pro-inflammatory mediators leading to endothelial damage and dysfunction $[4,8]$. Subsequently, adherent inflammatory cells transmigrate through the injured endothelium, attach to hepatocytes, and become fully activated to release oxidants and proteolytic enzymes, which in turn triggers the intracellular oxidative/nitrative stress and mitochondrial dysfunction in hepatocytes, eventually culminating in cell death (both apoptotic and necrotic), as also demonstrated in our report. Hepatic I/R also leads to significant reduction of endothelial NO synthase activity in sinusoidal endothelial cells during I/R [70-73] resulting in an imbalance between sinusoidal vasoconstrictors (e.g., endothelins) and vasodilators (NO) in the liver, creating a situation favoring sinusoidal vasoconstriction and injury during reperfusion $[4,70-72,74]$. In agreement with our recent results, and as already mentioned above, hepatic I/R also activates Kupffer cells, which in concert with activated inflammatory cells then produce proinflammatory cytokines, free radicals, oxidants, and large amounts of NO due to iNOS expression [4,56-60,75], leading to more sustained formation of peroxynitrite and decreased NO bioavailability. These events lead to further activation of endothelial cells, neutrophils, and hepatocytes, resulting in amplified ROS/RNS generation in the delayed phase of hepatic I/R aggravating the cell death of hepatocytes and consequent organ injury. 
Consistent with the above mentioned sequel of pathological events and previous reports using the same or very similar models [26-29], we have found increased serum alanine aminotransferase (ALT) and aspartate aminotransferase (AST) activities (markers of liver injury), hepatic oxidative/nitrative stress (HNE, NT content/staining, gp91phox and iNOS mRNA), mitochondrial dysfunction (decreased complex I activity), enhanced acute inflammatory response (TNF- $\alpha$, COX-2, MIP-1 $\alpha /$ CCL3, MIP-2/CXCL2, ICAM-1/CD54, mRNA levels, NF-KB), and stress signaling (p38 MAPK and JNK) activation at 2 and/or 6 hours of reperfusion. This was followed by tissue neutrophil infiltration and cell death (DNA fragmentation, PARP activity, and TUNEL) at 24 hours of reperfusion. Indeed, both oxidative and nitrative stress appeared to peak at 24 hours of reperfusion, as well as apoptotic cell death (DNA fragmentation and deoxynucleotidyl transferase dUTP nick end labeling (TUNEL)), while the poly(ADP-ribose) polymerase (PARP) activity was already at peak at 2-6 hours, indicating that the predominant type of cell death at the earlier time points of reperfusion is necrotic. The latter is also supported by peak observable levels of serum ALT and AST (marker of hepatocyte necrosis) at 6 hours of reperfusion in our model, and gradual return close to normal levels thereafter by 24 hours.

We found that $\mathrm{CBD}$, given prior to the induction of $\mathrm{I} / \mathrm{R}$, significantly attenuated the elevations of serum liver transaminases (ALT/AST), decreased tissue oxidative and nitrative stress (HNE, NT content/staining, gp91phox and iNOS expressions), attenuated acute and chronic hepatic inflammatory response (TNF- $\alpha$, MIP-1 $\alpha /$ CCL3, MIP-2/CXCL2, ICAM-1/ CD54, COX-2 mRNA levels, NF-KB activation, and tissue neutrophil infiltration), stress signaling (p38 MAPK, JNK), and cell death (DNA fragmentation, PARP activity and TUNEL). CBD also exerted similar protective effects in $\mathrm{CB}_{2}$ knockout mice against $\mathrm{I} / \mathrm{R}$ injury, indicating that its protective effects were not mediated by $\mathrm{CB}_{2}$ receptors. It is also unlikely that the in vitro described inverse agonistic property of $\mathrm{CBD}$ at $\mathrm{CB}_{2}$ receptors contributed to its beneficial effect observed in the current in vivo study, because $\mathrm{CB}_{2}$ inverse agonists by themselves are not attenuating the I/R-induced tissue (including hepatic) injury, but are able to prevent the protective effect of pure $\mathrm{CB}_{2}$ agonist in the same models [35]. Importantly from a clinical point of view, the protective effects of CBD against liver damage were also preserved when it was given right after the ischemic episode up to 90 minutes of reperfusion.

The beneficial effects of CBD against I/R injury can only be explained in part by its direct antioxidant properties [24,76]. In fact, in the first study demonstrating its direct and indirect antioxidant effects [24], CBD was more protective against glutamate-induced neurotoxicity than any of the well-know antioxidants (e.g., ascorbate or $\alpha$-tocopherol), indicating additional cytoprotective effects of CBD beyond its antioxidant properties. Moreover, prooxidant effects of CBD were also recently described in various immune cells (e.g. lymphocytes) in vitro $[77,78]$, which may contribute to apoptosis induction in these cells, an overall anti-inflammatory response. CBD has also been reported to exert potent antiinflammatory effects in numerous inflammatory disease models in which conventional antioxidants are not very effective (e.g., in autoimmune arthritis $[13,15,79]$ ), and was recently shown to attenuate key pro-inflammatory signaling processes (e.g. NF-KB activation) and/or its consequences (e.g. adhesion molecules, COX-2, iNOS expressions, etc.) in kidneys with nephropathy [38], diabetic hearts [25], human cardiomyocytes exposed to high glucose [25], and in bacterial lipopolysaccharide/endotoxin (LPS)-activated microglia cells [80], likewise in livers exposed to I/R injury in the current report. Notably, the most prominent effects of CBD in our in vivo liver I/R injury model were the suppression of the acute inflammatory response (orchestrated mostly by Kupffer cells and activated endothelium), as well as the marked attenuation of the delayed inflammatory cell infiltration. In further support of the anti-inflammatory effects of this natural constituent of marijuana, we also provide in vitro evidence that CBD attenuates LPS-triggered NF-KB 
activation and TNF- $\alpha$ production in isolated Kupffer cells, as well as the adhesion molecules (ICAM-1 and VCAM-1) expression in primary human liver sinusoidal endothelial cells stimulated with TNF- $\alpha$, likewise the attachment of human neutrophils to the activated endothelium. These protective effects of $\mathrm{CBD}$ were preserved in $\mathrm{CB}_{2}$ knockout mice and were not prevented by $\mathrm{CB}_{1 / 2}$ antagonists in vitro.

Although following intraperitoneal injection numerous biotransformation products of CBD has been reported in mouse livers, and over 50 metabolites were identified in the urine with considerable variations among rat, dog and man, their biological activities and significance are largely elusive [81,82]. On the basis of numerous in vitro studies (both in cell free and cellular systems; even though the metabolism of CBD can not be excluded in some cells in vitro), it is very likely CBD exerts direct anti-inflammatory and antioxidant effects. However, the indirect protective effect of its certain metabolites in in vivo models can not be excluded, which deserves further exploratory studies.

Collectively, our results indicate that CBD may represent a novel protective strategy against $\mathrm{I} / \mathrm{R}$-induced injury and inflammatory diseases by attenuating the acute and chronic proinflammatory response, oxidative/nitrative stress, cell death and interrelated signaling. Furthermore, our results also underline the importance of the careful evaluation of the markers of oxidative/nitrative stress, inflammation, cell death and signaling processes at various time points of reperfusion, since these may show considerable time-dependent differences.

\section{Acknowledgments}

This study was supported by the Intramural Research Program of NIH/NIAAA (to P.P.) and by NIDA grant \#9789 (to R.M.). Dr. Béla Horváth is a recipient of a Hungarian Research Council Scientific Research Fund Fellowship (OTKA-NKTH-EU MB08-80238). Authors are indebted to Drs. George Kunos and Bin Gao for providing key resources and support.

\section{References}

1. Liaudet L, Szabo G, Szabo C. Oxidative stress and regional ischemia-reperfusion injury: the peroxynitrite-poly(ADP-ribose) polymerase connection. Coron Artery Dis. 2003; 14:115-122. [PubMed: 12655275]

2. Ferdinandy P, Schulz R. Nitric oxide, superoxide, and peroxynitrite in myocardial ischaemiareperfusion injury and preconditioning. Br J Pharmacol. 2003; 138:532-543. [PubMed: 12598407]

3. Pacher P, Beckman JS, Liaudet L. Nitric oxide and peroxynitrite in health and disease. Physiol Rev. 2007; 87:315-424. [PubMed: 17237348]

4. Hines IN, Grisham MB. Divergent roles of superoxide and nitric oxide in liver ischemia and reperfusion injury. J Clin Biochem Nutr. 2011; 48:50-56. [PubMed: 21297912]

5. Szabo C. The pathophysiological role of peroxynitrite in shock, inflammation, and ischemiareperfusion injury. Shock. 1996; 6:79-88. [PubMed: 8856840]

6. Kupiec-Weglinski JW, Busuttil RW. Ischemia and reperfusion injury in liver transplantation. Transplant Proc. 2005; 37:1653-1656. [PubMed: 15919422]

7. Gero D, Szabo C. Role of the peroxynitrite-poly (ADP-ribose) polymerase pathway in the pathogenesis of liver injury. Curr Pharm Des. 2006; 12:2903-2910. [PubMed: 16918420]

8. Jaeschke H. Mechanisms of Liver Injury. II. Mechanisms of neutrophil-induced liver cell injury during hepatic ischemia-reperfusion and other acute inflammatory conditions. Am J Physiol Gastrointest Liver Physiol. 2006; 290:G1083-1088. [PubMed: 16687579]

9. Jaeschke H. Role of reactive oxygen species in hepatic ischemia-reperfusion injury and preconditioning. J Invest Surg. 2003; 16:127-140. [PubMed: 12775429] 
10. Ma XL, Lopez BL, Liu GL, Christopher TA, Ischiropoulos H. Peroxynitrite aggravates myocardial reperfusion injury in the isolated perfused rat heart. Cardiovasc Res. 1997; 36:195-204. [PubMed: 9463631]

11. Harada H, Hines IN, Flores S, Gao B, McCord J, Scheerens H, Grisham MB. Role of NADPH oxidase-derived superoxide in reduced size liver ischemia and reperfusion injury. Arch Biochem Biophys. 2004; 423:103-108. [PubMed: 14871473]

12. Urakami H, Abe Y, Grisham MB. Role of reactive metabolites of oxygen and nitrogen in partial liver transplantation: lessons learned from reduced-size liver ischaemia and reperfusion injury. Clin Exp Pharmacol Physiol. 2007; 34:912-919. [PubMed: 17645640]

13. Izzo AA, Borrelli F, Capasso R, Di Marzo V, Mechoulam R. Non-psychotropic plant cannabinoids: new therapeutic opportunities from an ancient herb. Trends Pharmacol Sci. 2009; 30:515-527. [PubMed: 19729208]

14. Howlett AC, Barth F, Bonner TI, Cabral G, Casellas P, Devane WA, Felder CC, Herkenham M, Mackie K, Martin BR, Mechoulam R, Pertwee RG. International Union of Pharmacology. XXVII. Classification of cannabinoid receptors. Pharmacol Rev. 2002; 54:161-202. [PubMed: 12037135]

15. Booz GW. Cannabidiol as an emergent therapeutic strategy for lessening the impact of inflammation on oxidative stress. Free Radic Biol Med. 201110.1016/j.freeradbiomed.2011.01.007

16. Barnes MP. Sativex: clinical efficacy and tolerability in the treatment of symptoms of multiple sclerosis and neuropathic pain. Expert Opin Pharmacother. 2006; 7:607-615. [PubMed: 16553576]

17. Thomas BF, Gilliam AF, Burch DF, Roche MJ, Seltzman HH. Comparative receptor binding analyses of cannabinoid agonists and antagonists. J Pharmacol Exp Ther. 1998; 285:285-292. [PubMed: 9536023]

18. Pertwee RG. Pharmacological actions of cannabinoids. Handb Exp Pharmacol. 2005:1-51. [PubMed: 16596770]

19. Pacher P, Batkai S, Kunos G. The endocannabinoid system as an emerging target of pharmacotherapy. Pharmacol Rev. 2006; 58:389-462. [PubMed: 16968947]

20. Pacher P, Mukhopadhyay P, Mohanraj R, Godlewski G, Batkai S, Kunos G. Modulation of the endocannabinoid system in cardiovascular disease: therapeutic potential and limitations. Hypertension. 2008; 52:601-607. [PubMed: 18779440]

21. Pacher P. Cannabinoid CB1 receptor antagonists for atherosclerosis and cardiometabolic disorders: new hopes, old concerns? Arterioscler Thromb Vasc Biol. 2009; 29:7-9. [PubMed: 19092136]

22. Cunha JM, Carlini EA, Pereira AE, Ramos OL, Pimentel C, Gagliardi R, Sanvito WL, Lander N, Mechoulam R. Chronic administration of cannabidiol to healthy volunteers and epileptic patients. Pharmacology. 1980; 21:175-185. [PubMed: 7413719]

23. Consroe P, Laguna J, Allender J, Snider S, Stern L, Sandyk R, Kennedy K, Schram K. Controlled clinical trial of cannabidiol in Huntington's disease. Pharmacol Biochem Behav. 1991; 40:701708. [PubMed: 1839644]

24. Hampson AJ, Grimaldi M, Axelrod J, Wink D. Cannabidiol and (-)Delta9-tetrahydrocannabinol are neuroprotective antioxidants. Proc Natl Acad Sci U S A. 1998; 95:8268-8273. [PubMed: 9653176]

25. Rajesh M, Mukhopadhyay P, Batkai S, Patel V, Saito K, Matsumoto S, Kashiwaya Y, Horvath B, Mukhopadhyay B, Becker L, Hasko G, Liaudet L, Wink DA, Veves A, Mechoulam R, Pacher P. Cannabidiol attenuates cardiac dysfunction, oxidative stress, fibrosis, and inflammatory and cell death signaling pathways in diabetic cardiomyopathy. J Am Coll Cardiol. 2010; 56:2115-2125. [PubMed: 21144973]

26. Abe Y, Hines IN, Zibari G, Pavlick K, Gray L, Kitagawa Y, Grisham MB. Mouse model of liver ischemia and reperfusion injury: method for studying reactive oxygen and nitrogen metabolites in vivo. Free Radic Biol Med. 2009; 46:1-7. [PubMed: 18955130]

27. Batkai S, Osei-Hyiaman D, Pan H, El-Assal O, Rajesh M, Mukhopadhyay P, Hong F, HarveyWhite J, Jafri A, Hasko G, Huffman JW, Gao B, Kunos G, Pacher P. Cannabinoid-2 receptor mediates protection against hepatic ischemia/reperfusion injury. FASEB J. 2007; 21:1788-1800. [PubMed: 17327359] 
28. Rajesh M, Pan H, Mukhopadhyay P, Batkai S, Osei-Hyiaman D, Hasko G, Liaudet L, Gao B, Pacher P. Cannabinoid-2 receptor agonist HU-308 protects against hepatic ischemia/reperfusion injury by attenuating oxidative stress, inflammatory response, and apoptosis. J Leukoc Biol. 2007; 82:1382-1389. [PubMed: 17652447]

29. Moon KH, Hood BL, Mukhopadhyay P, Rajesh M, Abdelmegeed MA, Kwon YI, Conrads TP, Veenstra TD, Song BJ, Pacher P. Oxidative inactivation of key mitochondrial proteins leads to dysfunction and injury in hepatic ischemia reperfusion. Gastroenterology. 2008; 135:1344-1357. [PubMed: 18778711]

30. Thomas A, Baillie GL, Phillips AM, Razdan RK, Ross RA, Pertwee RG. Cannabidiol displays unexpectedly high potency as an antagonist of $\mathrm{CB} 1$ and $\mathrm{CB} 2$ receptor agonists in vitro. $\mathrm{Br} \mathrm{J}$ Pharmacol. 2007; 150:613-623. [PubMed: 17245363]

31. Ignatowska-Jankowska B, Jankowski MM, Swiergiel AH. Cannabidiol decreases body weight gain in rats: Involvement of CB2 receptors. Neurosci Lett. 2011; 490:82-84. [PubMed: 21172406]

32. Zhang M, Martin BR, Adler MW, Razdan RK, Jallo JI, Tuma RF. Cannabinoid CB(2) receptor activation decreases cerebral infarction in a mouse focal ischemia/reperfusion model. J Cereb Blood Flow Metab. 2007; 27:1387-1396. [PubMed: 17245417]

33. Pacher P, Hasko G. Endocannabinoids and cannabinoid receptors in ischaemia-reperfusion injury and preconditioning. Br J Pharmacol. 2008; 153:252-262. [PubMed: 18026124]

34. Montecucco F, Lenglet S, Braunersreuther V, Burger F, Pelli G, Bertolotto M, Mach F, Steffens S. $\mathrm{CB}(2)$ cannabinoid receptor activation is cardioprotective in a mouse model of ischemia/ reperfusion. J Mol Cell Cardiol. 2009; 46:612-620. [PubMed: 19162037]

35. Pacher P, Mechoulam R. Is Lipid Signaling Through Cannabinoid 2 Receptors Part of a Protective System? Progress in Lipid Research. 2011 in press. 10.1016/j.plipres.2011.01.001

36. Mukhopadhyay P, Rajesh M, Pan H, Patel V, Mukhopadhyay B, Batkai S, Gao B, Hasko G, Pacher P. Cannabinoid-2 receptor limits inflammation, oxidative/nitrosative stress, and cell death in nephropathy. Free Radic Biol Med. 2010; 48:457-467. [PubMed: 19969072]

37. Gaoni Y, Mechoulam R. The isolation and structure of delta-1-tetrahydrocannabinol and other neutral cannabinoids from hashish. J Am Chem Soc. 1971; 93:217-224. [PubMed: 5538858]

38. Pan H, Mukhopadhyay P, Rajesh M, Patel V, Mukhopadhyay B, Gao B, Hasko G, Pacher P. Cannabidiol attenuates cisplatin-induced nephrotoxicity by decreasing oxidative/nitrosative stress, inflammation, and cell death. J Pharmacol Exp Ther. 2009; 328:708-714. [PubMed: 19074681]

39. Rajesh M, Mukhopadhyay P, Batkai S, Mukhopadhyay B, Patel V, Hasko G, Szabo C, Mabley JG, Liaudet L, Pacher P. Xanthine oxidase inhibitor allopurinol attenuates the development of diabetic cardiomyopathy. J Cell Mol Med. 2009; 13:2330-2341. [PubMed: 19175688]

40. Mukhopadhyay P, Rajesh M, Batkai S, Kashiwaya Y, Hasko G, Liaudet L, Szabo C, Pacher P. Role of superoxide, nitric oxide, and peroxynitrite in doxorubicin-induced cell death in vivo and in vitro. Am J Physiol Heart Circ Physiol. 2009; 296:H1466-1483. [PubMed: 19286953]

41. Forman HJ, Dickinson DA. Introduction to serial reviews on 4-hydroxy-2-nonenal as a signaling molecule. Free Radic Biol Med. 2004; 37:594-596. [PubMed: 15288117]

42. Forman HJ, Fukuto JM, Miller T, Zhang H, Rinna A, Levy S. The chemistry of cell signaling by reactive oxygen and nitrogen species and 4-hydroxynonenal. Arch Biochem Biophys. 2008; 477:183-195. [PubMed: 18602883]

43. Mukhopadhyay P, Rajesh M, Batkai S, Patel V, Kashiwaya Y, Liaudet L, Evgenov OV, Mackie K, Hasko G, Pacher P. CB1 cannabinoid receptors promote oxidative stress and cell death in murine models of doxorubicin-induced cardiomyopathy and in human cardiomyocytes. Cardiovasc Res. 2010; 85:773-784. [PubMed: 19942623]

44. Mukhopadhyay P, Horvath B, Rajesh M, Matsumoto S, Saito K, Batkai S, Patel V, Tanchian G, Gao RY, Cravatt BF, Hasko G, Pacher P. Fatty acid amide hydrolase is a key regulator of endocannabinoid-induced myocardial tissue injury. Free Radic Biol Med. 2011; 50:179-195. [PubMed: 21070851]

45. Rajesh M, Mukhopadhyay P, Batkai S, Hasko G, Liaudet L, Huffman JW, Csiszar A, Ungvari Z, Mackie K, Chatterjee S, Pacher P. CB2-receptor stimulation attenuates TNF-alpha-induced human endothelial cell activation, transendothelial migration of monocytes, and monocyte-endothelial adhesion. Am J Physiol Heart Circ Physiol. 2007; 293:H2210-2218. [PubMed: 17660390] 
46. Eiserich JP, Hristova M, Cross CE, Jones AD, Freeman BA, Halliwell B, van der Vliet A. Formation of nitric oxide-derived inflammatory oxidants by myeloperoxidase in neutrophils. Nature. 1998; 391:393-397. [PubMed: 9450756]

47. Baldus S, Eiserich JP, Brennan ML, Jackson RM, Alexander CB, Freeman BA. Spatial mapping of pulmonary and vascular nitrotyrosine reveals the pivotal role of myeloperoxidase as a catalyst for tyrosine nitration in inflammatory diseases. Free Radic Biol Med. 2002; 33:1010. [PubMed: 12361810]

48. Radi R. Nitric oxide, oxidants, and protein tyrosine nitration. Proc Natl Acad Sci U S A. 2004; 101:4003-4008. [PubMed: 15020765]

49. Engerson TD, McKelvey TG, Rhyne DB, Boggio EB, Snyder SJ, Jones HP. Conversion of xanthine dehydrogenase to oxidase in ischemic rat tissues. J Clin Invest. 1987; 79:1564-1570. [PubMed: 3294898]

50. Jaeschke H. Molecular mechanisms of hepatic ischemia-reperfusion injury and preconditioning. Am J Physiol Gastrointest Liver Physiol. 2003; 284:G15-26. [PubMed: 12488232]

51. Veitch K, Hombroeckx A, Caucheteux D, Pouleur H, Hue L. Global ischaemia induces a biphasic response of the mitochondrial respiratory chain. Anoxic pre-perfusion protects against ischaemic damage. Biochem J. 1992; 281(Pt 3):709-715. [PubMed: 1346958]

52. Bouaziz N, Redon M, Quere L, Remacle J, Michiels C. Mitochondrial respiratory chain as a new target for anti-ischemic molecules. Eur J Pharmacol. 2002; 441:35-45. [PubMed: 12007918]

53. Ma TT, Ischiropoulos H, Brass CA. Endotoxin-stimulated nitric oxide production increases injury and reduces rat liver chemiluminescence during reperfusion. Gastroenterology. 1995; 108:463469. [PubMed: 7835589]

54. Szabo C, Ischiropoulos H, Radi R. Peroxynitrite: biochemistry, pathophysiology and development of therapeutics. Nat Rev Drug Discov. 2007; 6:662-680. [PubMed: 17667957]

55. Radi R, Cassina A, Hodara R, Quijano C, Castro L. Peroxynitrite reactions and formation in mitochondria. Free Radic Biol Med. 2002; 33:1451-1464. [PubMed: 12446202]

56. Tsung A, Stang MT, Ikeda A, Critchlow ND, Izuishi K, Nakao A, Chan MH, Jeyabalan G, Yim $\mathrm{JH}$, Geller DA. The transcription factor interferon regulatory factor-1 mediates liver damage during ischemia-reperfusion injury. Am J Physiol Gastrointest Liver Physiol. 2006; 290:G12611268. [PubMed: 16410367]

57. Tanaka H, Uchida Y, Kaibori M, Hijikawa T, Ishizaki M, Yamada M, Matsui K, Ozaki T, Tokuhara K, Kamiyama Y, Nishizawa M, Ito S, Okumura T. Na+/H+ exchanger inhibitor, FR183998, has protective effect in lethal acute liver failure and prevents iNOS induction in rats. J Hepatol. 2008; 48:289-299. [PubMed: 18096265]

58. Yoshida H, Kwon AH, Kaibori M, Tsuji K, Habara K, Yamada M, Kamiyama Y, Nishizawa M, Ito $\mathrm{S}$, Okumura T. Edaravone prevents iNOS expression by inhibiting its promoter transactivation and mRNA stability in cytokine-stimulated hepatocytes. Nitric Oxide. 2008; 18:105-112. [PubMed: 18078833]

59. Hamada T, Duarte S, Tsuchihashi S, Busuttil RW, Coito AJ. Inducible nitric oxide synthase deficiency impairs matrix metalloproteinase-9 activity and disrupts leukocyte migration in hepatic ischemia/reperfusion injury. Am J Pathol. 2009; 174:2265-2277. [PubMed: 19443702]

60. Yun N, Eum HA, Lee SM. Protective role of heme oxygenase-1 against liver damage caused by hepatic ischemia and reperfusion in rats. Antioxid Redox Signal. 2010; 13:1503-1512. [PubMed: 20446775]

61. Pesse B, Levrand S, Feihl F, Waeber B, Gavillet B, Pacher P, Liaudet L. Peroxynitrite activates ERK via Raf-1 and MEK, independently from EGF receptor and p21Ras in H9C2 cardiomyocytes. J Mol Cell Cardiol. 2005; 38:765-775. [PubMed: 15850570]

62. Levrand S, Vannay-Bouchiche C, Pesse B, Pacher P, Feihl F, Waeber B, Liaudet L. Peroxynitrite is a major trigger of cardiomyocyte apoptosis in vitro and in vivo. Free Radic Biol Med. 2006; 41:886-895. [PubMed: 16934671]

63. Loukili N, Rosenblatt-Velin N, Rolli J, Levrand S, Feihl F, Waeber B, Pacher P, Liaudet L. Oxidants positively or negatively regulate nuclear factor kappaB in a context-dependent manner. $\mathrm{J}$ Biol Chem. 2010; 285:15746-15752. [PubMed: 20299457] 
64. Loukili N, Rosenblatt-Velin N, Li J, Clerc S, Pacher P, Feihl F, Waeber B, Liaudet L. Peroxynitrite induces HMGB1 release by cardiac cells in vitro and HMGB1 upregulation in the infarcted myocardium in vivo. Cardiovasc Res. 2011; 89:586-594. [PubMed: 21113057]

65. Zeng S, Feirt N, Goldstein M, Guarrera J, Ippagunta N, Ekong U, Dun H, Lu Y, Qu W, Schmidt AM, Emond JC. Blockade of receptor for advanced glycation end product (RAGE) attenuates ischemia and reperfusion injury to the liver in mice. Hepatology. 2004; 39:422-432. [PubMed: 14767995]

66. Zwacka RM, Zhou W, Zhang Y, Darby CJ, Dudus L, Halldorson J, Oberley L, Engelhardt JF. Redox gene therapy for ischemia/reperfusion injury of the liver reduces AP1 and NF-kappaB activation. Nat Med. 1998; 4:698-704. [PubMed: 9623979]

67. Teoh N, Field J, Sutton J, Farrell G. Dual role of tumor necrosis factor-alpha in hepatic ischemiareperfusion injury: studies in tumor necrosis factor-alpha gene knockout mice. Hepatology. 2004; 39:412-421. [PubMed: 14767994]

68. Ito Y, Katagiri H, Ishii K, Kakita A, Hayashi I, Majima M. Effects of selective cyclooxygenase inhibitors on ischemia/reperfusion-induced hepatic microcirculatory dysfunction in mice. Eur Surg Res. 2003; 35:408-416. [PubMed: 12928598]

69. Hamada T, Tsuchihashi S, Avanesyan A, Duarte S, Moore C, Busuttil RW, Coito AJ. Cyclooxygenase-2 deficiency enhances $\mathrm{Th} 2$ immune responses and impairs neutrophil recruitment in hepatic ischemia/reperfusion injury. J Immunol. 2008; 180:1843-1853. [PubMed: 18209082]

70. Lee VG, Johnson ML, Baust J, Laubach VE, Watkins SC, Billiar TR. The roles of iNOS in liver ischemia-reperfusion injury. Shock. 2001; 16:355-360. [PubMed: 11699073]

71. Harbrecht BG, Billiar TR. The role of nitric oxide in Kupffer cell-hepatocyte interactions. Shock. 1995; 3:79-87. [PubMed: 7538434]

72. Billiar TR. Nitric oxide. Novel biology with clinical relevance. Ann Surg. 1995; 221:339-349. [PubMed: 7537035]

73. Hines IN, Kawachi S, Harada H, Pavlick KP, Hoffman JM, Bharwani S, Wolf RE, Grisham MB. Role of nitric oxide in liver ischemia and reperfusion injury. Mol Cell Biochem. 2002; 234235:229-237.

74. Hines IN, Harada H, Flores S, Gao B, McCord JM, Grisham MB. Endothelial nitric oxide synthase protects the post-ischemic liver: potential interactions with superoxide. Biomed Pharmacother. 2005; 59:183-189. [PubMed: 15862713]

75. Ischiropoulos H, Zhu L, Beckman JS. Peroxynitrite formation from macrophage-derived nitric oxide. Arch Biochem Biophys. 1992; 298:446-451. [PubMed: 1329657]

76. Hamelink C, Hampson A, Wink DA, Eiden LE, Eskay RL. Comparison of cannabidiol, antioxidants, and diuretics in reversing binge ethanol-induced neurotoxicity. J Pharmacol Exp Ther. 2005; 314:780-788. [PubMed: 15878999]

77. Wu HY, Chu RM, Wang CC, Lee CY, Lin SH, Jan TR. Cannabidiol-induced apoptosis in primary lymphocytes is associated with oxidative stress-dependent activation of caspase- 8 . Toxicol Appl Pharmacol. 2008; 226:260-270. [PubMed: 17950393]

78. Wu HY, Chang AC, Wang CC, Kuo FH, Lee CY, Liu DZ, Jan TR. Cannabidiol induced a contrasting pro-apoptotic effect between freshly isolated and precultured human monocytes. Toxicol Appl Pharmacol. 2010

79. Malfait AM, Gallily R, Sumariwalla PF, Malik AS, Andreakos E, Mechoulam R, Feldmann M. The nonpsychoactive cannabis constituent cannabidiol is an oral anti-arthritic therapeutic in murine collagen-induced arthritis. Proc Natl Acad Sci U S A. 2000; 97:9561-9566. [PubMed: 10920191]

80. Kozela E, Pietr M, Juknat A, Rimmerman N, Levy R, Vogel Z. Cannabinoids Delta(9)tetrahydrocannabinol and cannabidiol differentially inhibit the lipopolysaccharide-activated NFkappaB and interferon-beta/STAT proinflammatory pathways in BV-2 microglial cells. J Biol Chem. 2010; 285:1616-1626. [PubMed: 19910459]

81. Martin BR, Harvey DJ, Paton WD. Biotransformation of cannabidiol in mice. Identification of new acid metabolites. Drug Metab Dispos. 1977; 5:259-267. [PubMed: 17524]

82. Harvey DJ, Samara E, Mechoulam R. Comparative metabolism of cannabidiol in dog, rat and man. Pharmacol Biochem Behav. 1991; 40:523-532. [PubMed: 1806942] 

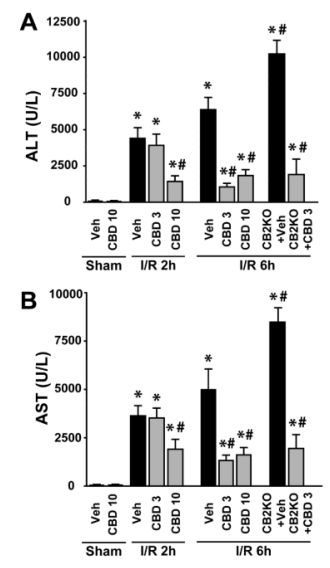

Figure 1. Cannabidiol pretreatment decreases liver I/R injury

Panel A-B: Serum transaminase ALT $(A)$ and AST $(B)$ levels in sham operated mice treated with vehicle (veh) or CBD ( $n=5 /$ group) or in mice exposed to $1 \mathrm{~h}$ of hepatic ischemia followed by 2 or 6 hours of reperfusion pretreated with vehicle or CBD (3 or $10 \mathrm{mg} / \mathrm{kg}$, $n=7-12$ /group). $* \mathrm{P}<0.05$ vs. vehicle-sham group; $\# \mathrm{P}<0.05$ vs. corresponding control or cannabinoid 2 receptor knockout $(\mathrm{CB} 2 \mathrm{KO})$ mice exposed to vehicle-I/R. 


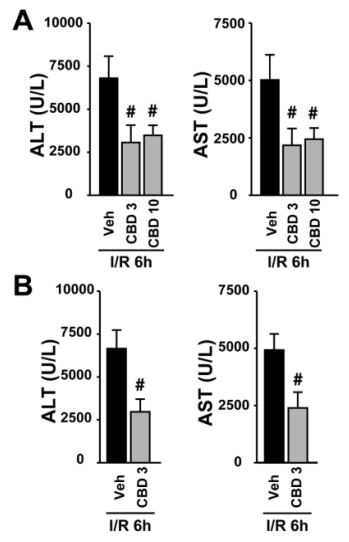

Figure 2. Cannabidiol treatment after ischemia or at 90 mins of reperfusion decreases liver I/R injury

Panel A and B: Serum transaminase ALT and AST levels in mice exposed to $1 \mathrm{~h}$ of hepatic ischemia followed by 6 hours of reperfusion treated with vehicle or CBD (3 or $10 \mathrm{mg} / \mathrm{kg}$, $n=5-7 /$ group) either right after the ischemia before reperfusion (panel A) or at 90 minutes of reperfusion (panel B). \#P<0.05 vs. corresponding mice exposed to vehicle-I/R. 


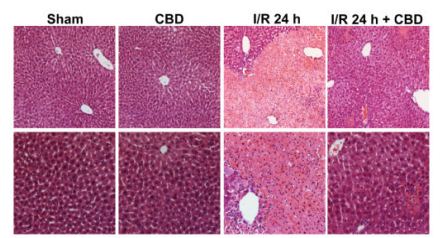

Figure 3. Cannabidiol decreases histological damage $24 \mathrm{~h}$ following ischemia

Hematoxylin and eosin staining of representative liver sections of sham mice treated with vehicle (sham) or CBD (CBD), and mice exposed to 1 hour of ischemia followed by 24 hours of reperfusion, treated with vehicle (I/R) or CBD (I/R+CBD). A similar histological profile was seen in three to five livers/group. Upper row of images depicts 200x magnification, while the lower one 400x magnification. 

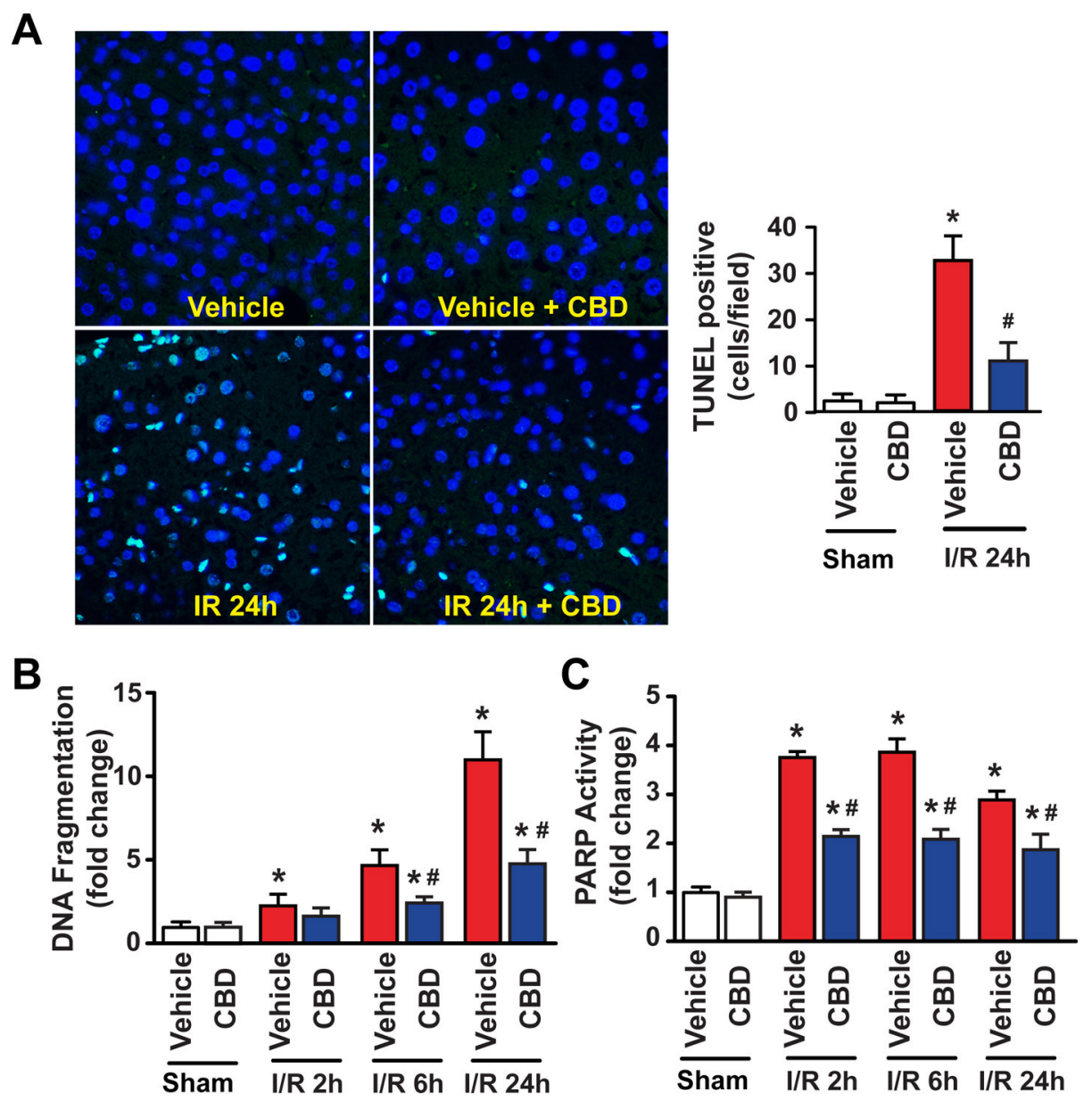

Figure 4. Cannabidiol attenuates I/R-induced enhanced hepatic cell death

Panels A: Representative TUNEL staining $24 \mathrm{~h}$ following I/R injury. TUNEL positive nuclei of cells are light blue/white (colocalization of TUNEL (green staining) with nuclear staining (blue)), whereas the dark blue staining represents the staining of nuclei of normal cells. Right panel: quantification of hepatic TUNEL staining. Results are mean \pm SEM of $10-12$ frames/group from 3-4 different animals/group. $* \mathrm{P}<0.05$ vs. sham vehicle; $\# \mathrm{P}<0.05$ vs. I/R vehicle mice.

Panels B: Time-dependent increase of hepatic DNA fragmentation demonstrated following $\mathrm{I} / \mathrm{R}$ injury and attenuation by $\mathrm{CBD}$ pretreatment at $10 \mathrm{mg} / \mathrm{kg}$. Results are mean $\pm \mathrm{SEM}$ of $\mathrm{n}=8$ /group.

$* \mathrm{P}<0.05$ vs. sham vehicle; $\# \mathrm{P}<0.05$ vs. corresponding $\mathrm{I} / \mathrm{R}$ mice.

Panels C: Time dependent changes in hepatic PARP activity following I/R, and attenuation of the observed increases by pretreatment with CBD at $10 \mathrm{mg} / \mathrm{kg}$. Results are mean $\pm \mathrm{SEM}$ of $\mathrm{n}=8 /$ group. $* \mathrm{P}<0.05$ vs. sham vehicle; $\# \mathrm{P}<0.05$ vs. corresponding I/R mice. 

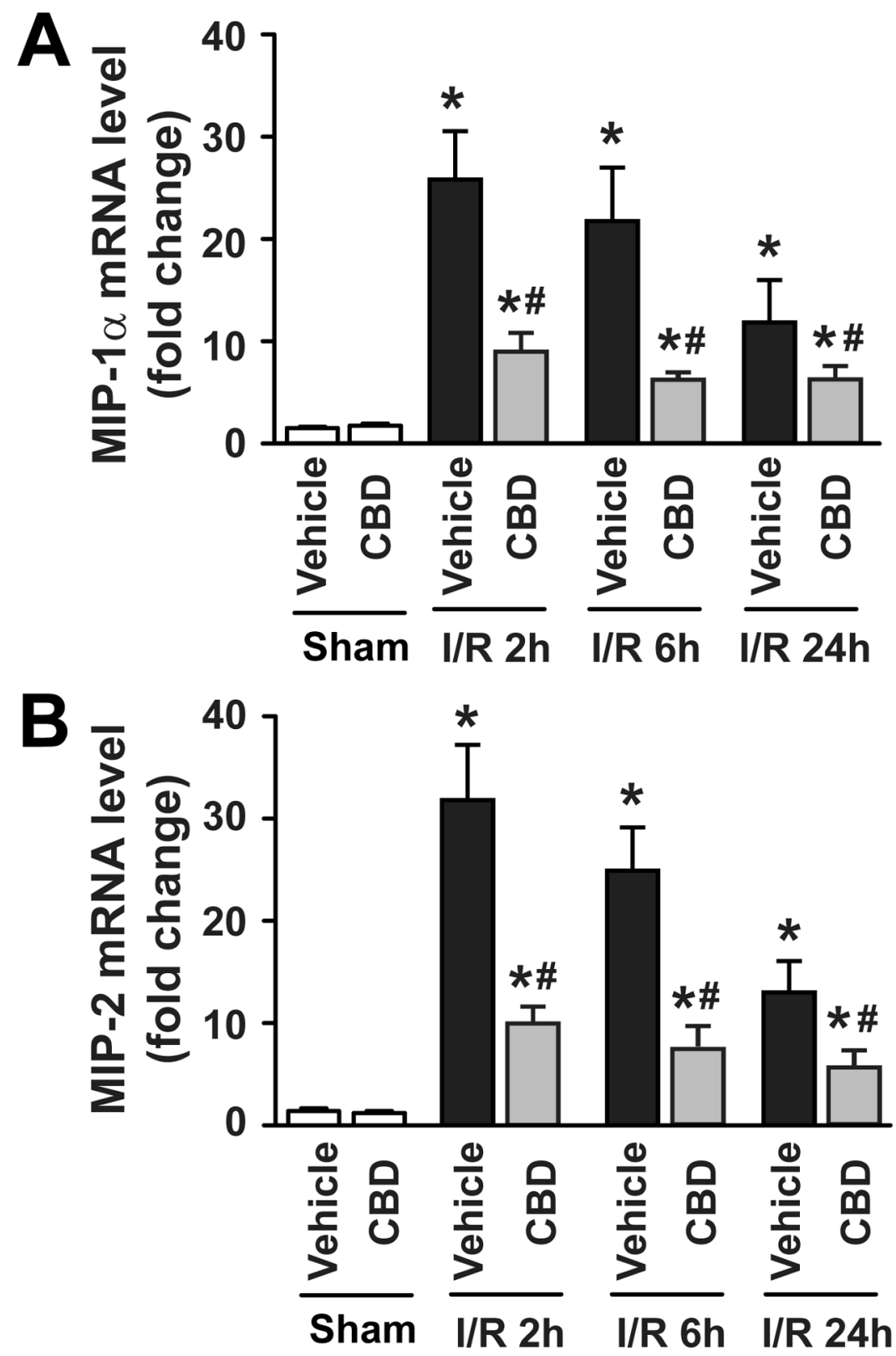

Figure 5. Cannabidiol attenuates I/R-induced acute pro-inflammatory chemokines response in the liver

Panels A: Real-time PCR shows significant increase of chemokine MIP-1 $\alpha$ (CCL3) mRNA level at 2 hours of reperfusion (IR 2h), and a decrease at 24 hours of reperfusion (IR $24 \mathrm{~h}$ ). Pretreatment with CBD at $10 \mathrm{mg} / \mathrm{kg}$ significantly attenuates the I/R-induced increased proinflammatory chemokine levels at all time points of the reperfusion studied (2, 6 and 24 hours).

Panels B: Real-time PCR shows significant increase of chemokine MIP-2 (CXCL2) mRNA level at $2 \mathrm{~h}$ of reperfusion (IR 2h), and a decrease at 24 hours of reperfusion (IR 24h).

Pretreatment with CBD at $10 \mathrm{mg} / \mathrm{kg}$ attenuates the I/R-induced increased pro-inflammatory chemokine levels at all time points of the reperfusion studied (2, 6 and 24 hours).

Results are mean \pm SEM of $6-12$ mice/groups. $* \mathrm{P}<0.05$ vs. vehicle-sham group; \#P<0.05 vs. corresponding vehicle-I/R mice. 


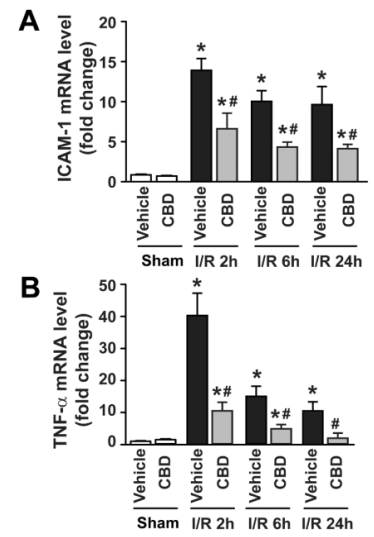

Figure 6. Cannabidiol attenuates I/R-induced increased adhesion molecule expression and acute pro-inflammatory cytokine TNF- $\alpha$ response in the liver

Panels A: Real-time PCR shows significant increase of hepatic adhesion molecule ICAM-1 mRNA level at 2 hours of reperfusion (IR 2h), which was further attenuated at 6 and 24 hours of reperfusion (I/R $6 \mathrm{~h}$ and $24 \mathrm{~h}$ ). Pretreatment with CBD at $10 \mathrm{mg} / \mathrm{kg}$ significantly attenuates the I/R-induced increased hepatic ICAM-1 expression at all time points of the reperfusion studied (2, 6 and 24 hours).

Panels B: Real-time PCR shows significant increase of hepatic pro-inflammatory cytokine TNF- $\alpha$ mRNA level at $2 \mathrm{~h}$ of reperfusion (IR $2 \mathrm{~h}$ ), and a gradual decrease with time. Pretreatment with CBD at $10 \mathrm{mg} / \mathrm{kg}$ attenuates the I/R-induced increased hepatic TNF- $\alpha$ mRNA level at all time points of reperfusion studied (2, 6 and 24 hours).

Results are mean \pm SEM of 6-12 mice/groups. *P<0.05 vs. vehicle-sham group; \#P<0.05 vs. corresponding vehicle-I/R mice. 


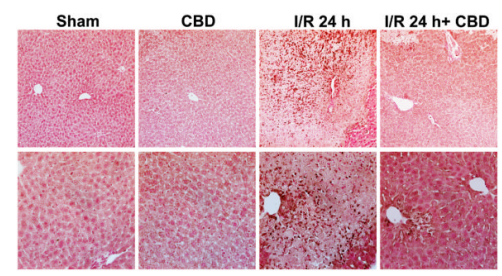

Figure 7. Cannabidiol decreases I/R-induced neutrophil infiltration after I/R injury Myeloperoxidase staining (brown) of representative liver sections of sham mice pretreated with vehicle (sham) or CBD (CBD), and mice exposed to 1 hour of hepatic ischemia followed by 24 hours of reperfusion with vehicle (I/R) or CBD (I/R+CBD) pretreatment. I/R followed by 24 hours of reperfusion dramatically increased neutrophil infiltrationin in the livers, which was attenuated by CBD pretreatment. In livers of sham operated mice with or without pretreatment there was no tissue inflammatory cell infiltration, likewise only a very few inflammatory cells were present in the lumen of some vessels at 2 hours and 6 of reperfusion. Slides were counterstained by nuclear fast red. A similar histological profile was seen in three to five livers/group. Upper row of images depicts 200x magnification, while the lower one 400x magnification. 


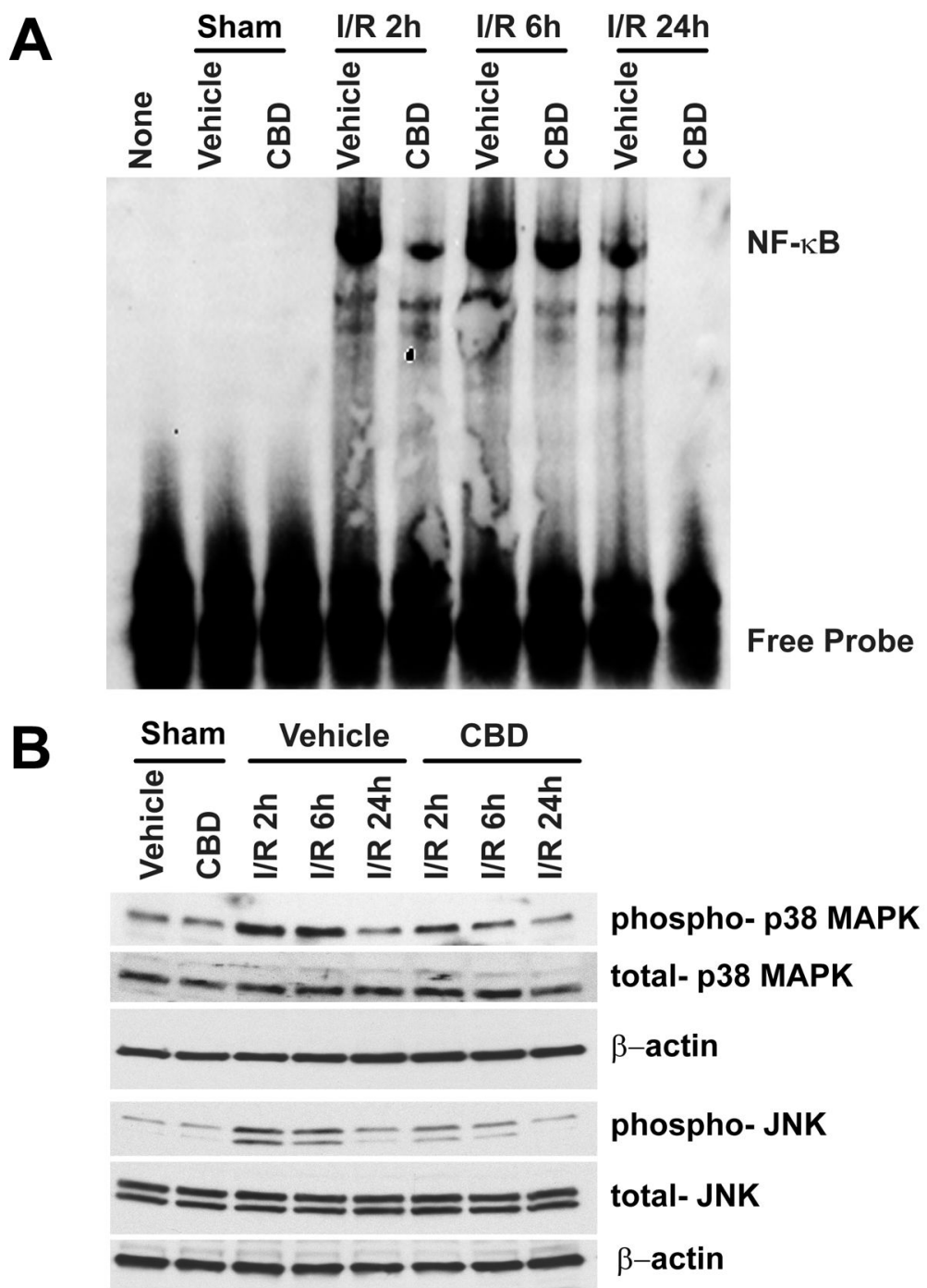

Figure 8. Cannabidiol attenuates I/R-induced hepatic NF-kB activation and p38 MAPK and JNK phosphorylation

Panel A: The gel shift assay demonstrates NF- $\kappa$ B activation at 2 and 6 hours of reperfusion (I/R $2 \mathrm{~h}$ and I/R 6h) which was attenuated at 24 hours reperfusion (I/R 24h). CBD pretreatment at $10 \mathrm{mg} / \mathrm{kg}$ attenuates these activation at all time points of reperfusion studied. Panel B: Marked increase in the p38MAPK and c-Jun N-terminal kinase (JNK) activation in I/R liver tissues of mice at 2 and 6 hours following I/R injury, which are attenuated by CBD pretreatment at $10 \mathrm{mg} / \mathrm{kg}$. $\beta$-actin is used as loading control. 


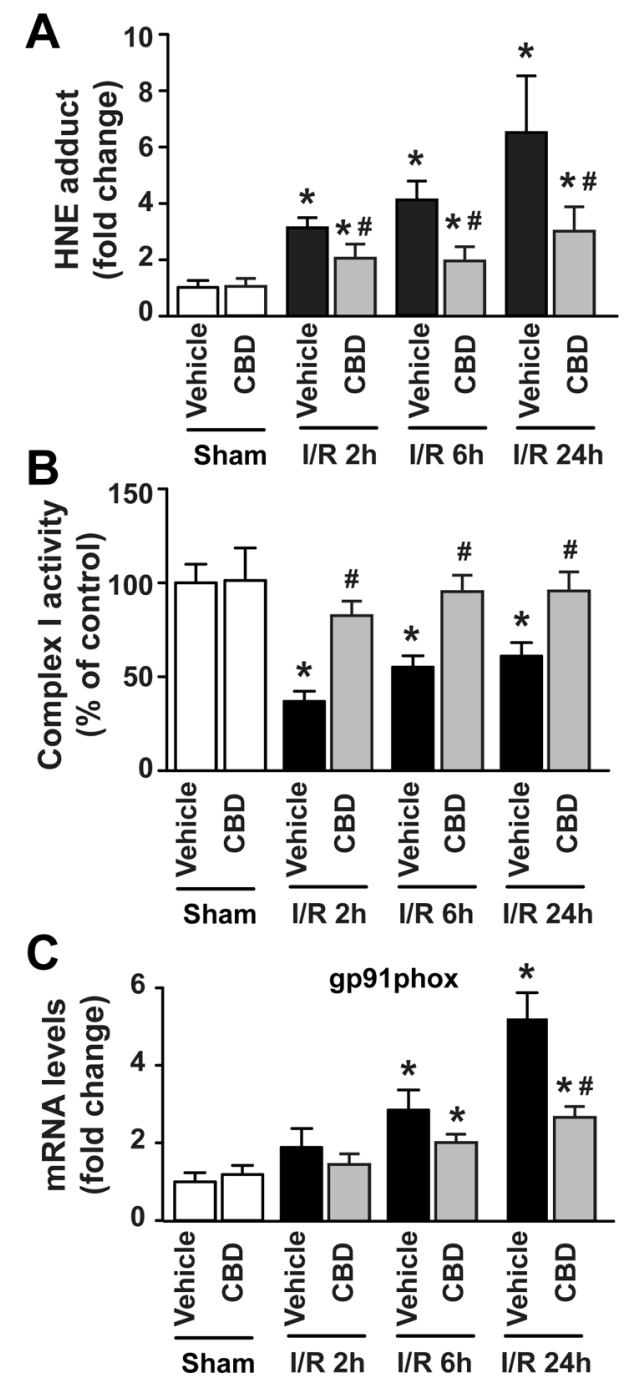

Figure 9. Cannabidiol decreases the I/R-induced increased hepatic oxidative stress and restores decreased mitochondrial complex I activity

Panel A: HNE adduct, a marker for lipid peroxidation/oxidative stress, increases with time following I/R injury, and CBD pretreatment at $10 \mathrm{mg} / \mathrm{kg}$ attenuates these increases at all time points of reperfusion studied (2, 6 and 24 hours). Results are mean \pm SEM of 8 mice/ groups. ${ }^{*} \mathrm{P}<0.05$ vs. vehicle-sham group; \#P<0.05 vs. corresponding vehicle-I/R mice. Panel B: Mitochondrial complex I activity decreased at 2 hours of reperfusion which partially recovered at 6 and 24 hours of reperfusion. Pretreatment with CBD at $10 \mathrm{mg} / \mathrm{kg}$ attenuated the I/R-induced decreased mitochondrial complex I at all time points of the reperfusion studied (2, 6 and 24 hours). Results are mean \pm SEM of 6-7 mice/groups. $* \mathrm{P}<0.05$ vs. vehicle-sham group; \# $\mathrm{P}<0.05$ vs. corresponding vehicle-I/R mice.

Panel C: Real-time PCR shows significant increase of hepatic gp91phox mRNA level from 6 hours of reperfusion (IR 6h), which peaks at 24 hours (IR 24h). Pretreatment with CBD at $10 \mathrm{mg} / \mathrm{kg}$ significantly attenuates the I/R-induced increased liver gp91phox mRNA expression at 6 and 24 hours of reperfusion. Results are mean \pm SEM of 8-10 mice/groups. $* \mathrm{P}<0.05$ vs. vehicle-sham group; \# $\mathrm{P}<0.05$ vs. corresponding vehicle-I/R mice. 

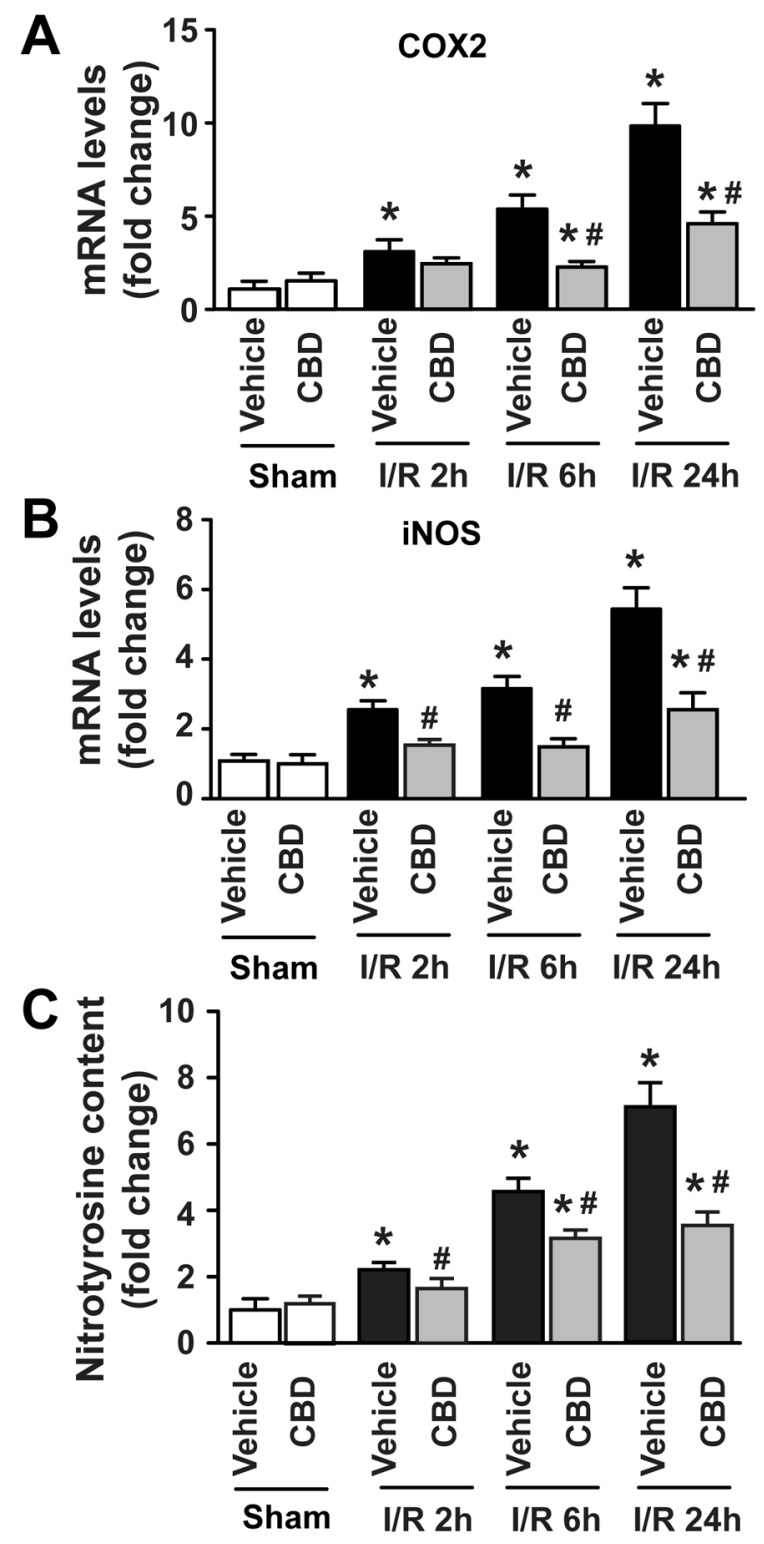

Figure 10. Cannabidiol attenuates I/R-induced COX-2 and iNOS mRNA expression and nitrative stress in the liver

Panel A: Real-time PCR shows significant time-dependent increases of hepatic COX-2 mRNA level at 2, 6 and 24 hours of reperfusion (IR 2h, $6 \mathrm{~h}$ and $24 \mathrm{~h}$ ). Pretreatment with CBD at $10 \mathrm{mg} / \mathrm{kg}$ attenuates the I/R-induced increase in COX-2 mRNA expression at all time points of the reperfusion studied (2, 6 and 24 hours). Results are mean \pm SEM of 6-10 mice/ groups. $* \mathrm{P}<0.05$ vs. vehicle-sham group; \#P<0.05 vs. corresponding vehicle-I/R mice. Panel B: Real-time PCR shows significant time-dependent increases of hepatic iNOS mRNA level at 2, 6 and 24 hours of reperfusion (IR 2h, $6 \mathrm{~h}$ and $24 \mathrm{~h}$ ). Pretreatment with CBD at $10 \mathrm{mg} / \mathrm{kg}$ attenuates the I/R-induced increase in iNOS mRNA at all time points of the reperfusion studied (2, 6 and 24 hours). Results are mean \pm SEM of 6-10 mice/groups. $* \mathrm{P}<0.05$ vs. vehicle-sham group; \# $\mathrm{P}<0.05$ vs. corresponding vehicle-I/R mice.

Panels C: Nitrotyrosine modification of protein, a marker for nitrative stress, increases with time following I/R injury, and CBD pretreatment at $10 \mathrm{mg} / \mathrm{kg}$ attenuates these increases at all time points of reperfusion studied (2, 6 and 24 hours). 
Results are mean \pm SEM for both panels and $n=8-12$ /group. $* \mathrm{P}<0.05$ vs. vehicle; $\# \mathrm{P}<0.05$ vs. corresponding vehicle-I/R mice. 


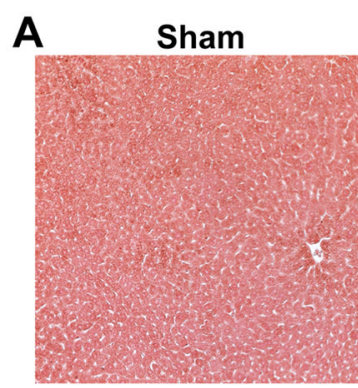

B

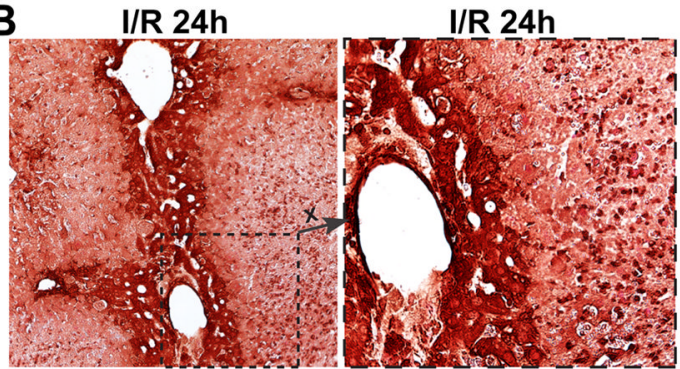

C

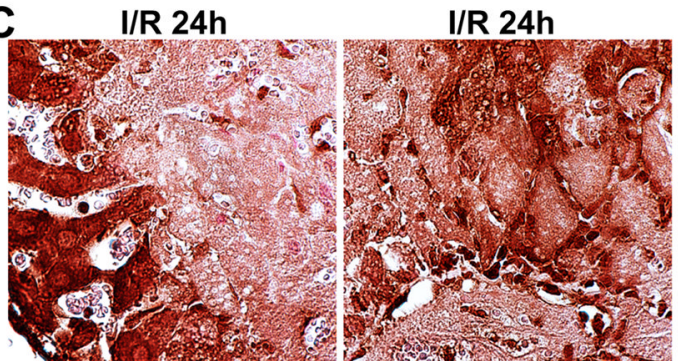

Nitrotyrosine

I/R $6 h$

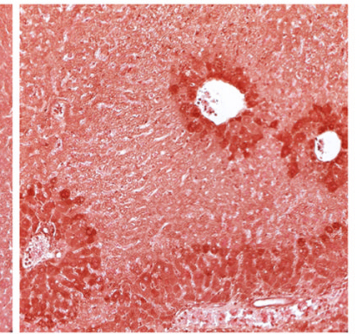

I/R 24h
I/R $6 h+C B D$

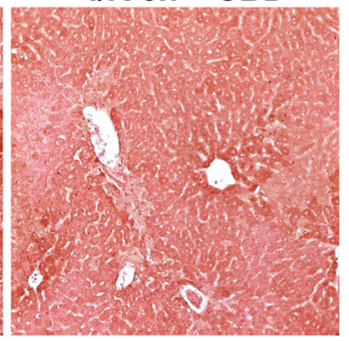

I/R 24h + CBD
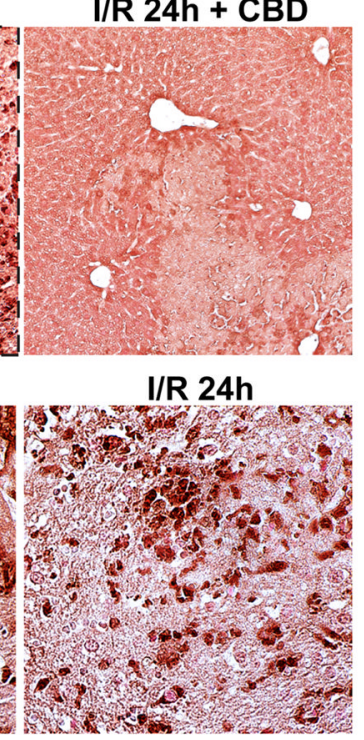

Figure 11. Cannabidiol attenuates I/R-induced hepatic nitrotyrosine staining Panel A: Increased nitrotyrosine staining after 6 hours of liver reperfusion in perivascular area (endothelial cells and surrounding layers of hepatocytes), which was attenuated by CBD treatment (200x magnification). Similar pattern, but weaker staining was seen at 2 hours of reperfusion (not shown).

Panel B: Very strong hepatic nitrotyrosine staining in perivascular area at 24 hours of reperfusion (200x magnification). On the magnified insert (middle image) it is clearly shown that the strong nitrotyrosine staining was present in hepatocytes around the vessels, endothelial cells, and in inflammatory infiltrate (neutrophil granulocytes, macrophages, etc.). CBD was able to attenuate the $\mathrm{I} / \mathrm{R}$-induced nitrotyrosine formation.

Panel $\mathrm{C}$ shows further details of nitrotyrosine staining after 24 hours of reperfusion with a $1000 x$ magnification in endothelial cells, hepatocytes and in the inflammatory infiltrate. Similar staining was seen in 4 to 6 livers/group. 


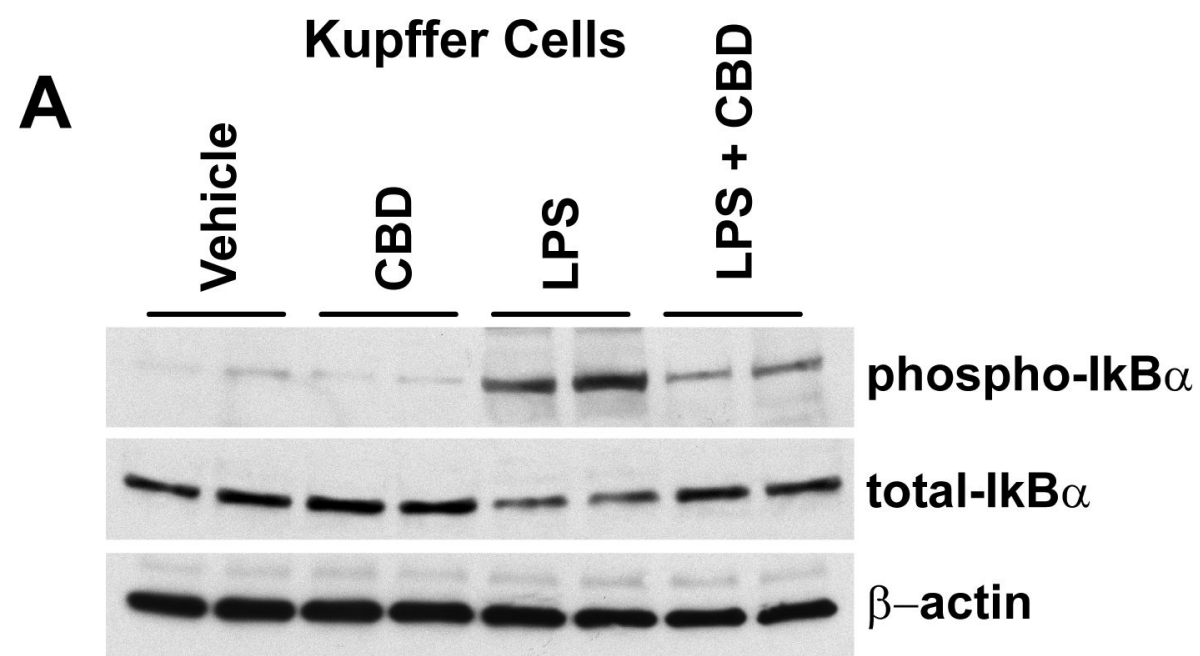

B

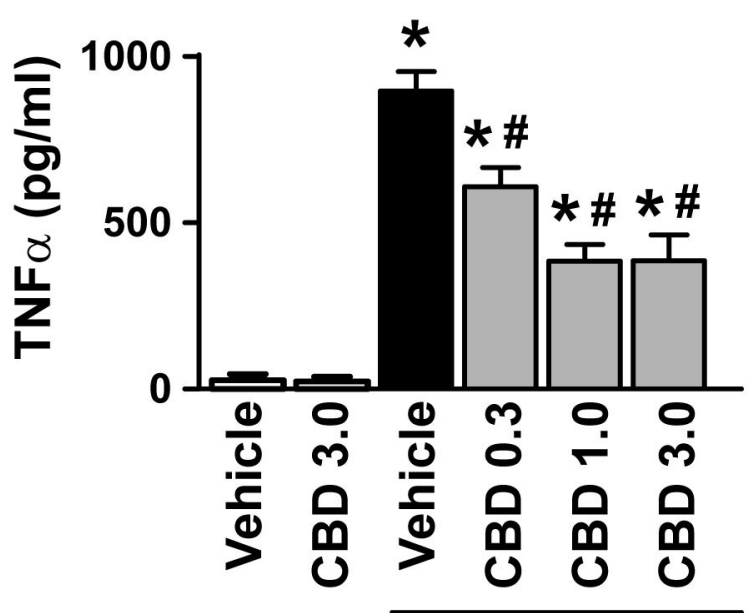

LPS $100 \mathrm{ng} / \mathrm{ml}$

Figure 12. Cannabidiol attenuates LPS-induced NF-אB activation and TNF $\alpha$ secretion in Kupffer cells

Panel A: Western blot analysis demonstrates inhibition of nuclear transcription factor NF- $\kappa \mathrm{B}$ $(\mathrm{I} \kappa \mathrm{B})$ expression and its phosphorylation in the cytosolic fraction. CBD attenuates LPS induced phosphorylation of IкB in Kupffer cells. $\beta$-Actin is used as loading control. Panel B: CBD (0.3-3 $\mu \mathrm{M})$ attenuates LPS induced TNF $\alpha$ secretion of Kupffer cells in dosedependent manner. Results are mean \pm SEM of $n=4-6$ /group. $* \mathrm{P}<0.05$ vs. vehicle; $\# \mathrm{P}<0.05$ vs. LPS. 

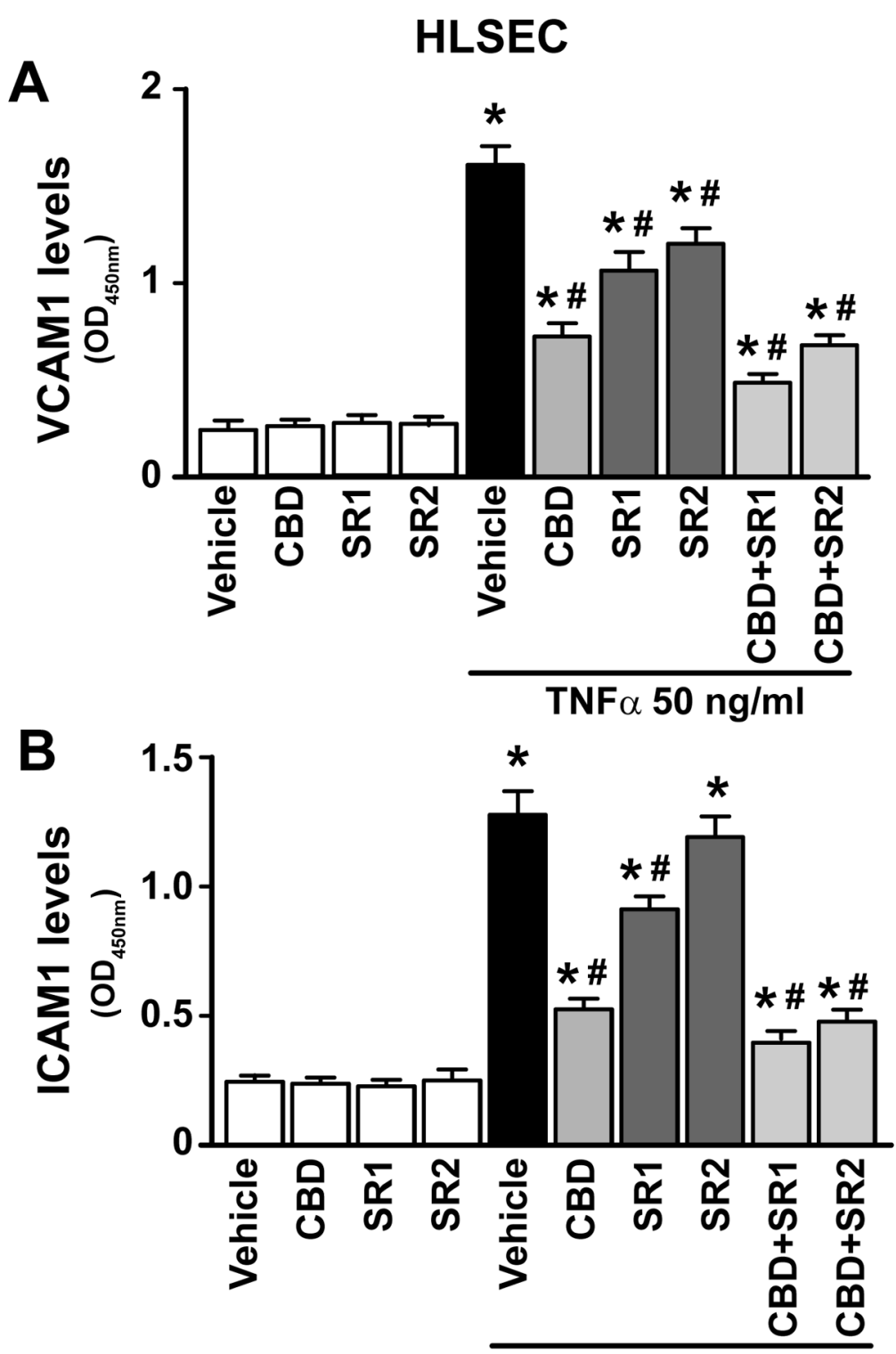

$\mathrm{TNF} \alpha 50 \mathrm{ng} / \mathrm{ml}$

Figure 13. Cannabidiol attenuates the TNF- $\alpha$ induced adhesion molecules expression in human liver sinusoidal endothelial cells (HLSEC)

Treatment of HLSEC cells with TNF- $\alpha$ for $6 \mathrm{hrs}$ markedly enhances the expression of adhesion molecules such as ICAM-1 and VCAM-1. CBD $(1 \mu \mathrm{M})$ attenuates this enhanced expression of adhesion molecules ICAM-1 (Panel A) and VCAM-1 (Panel B). Cannabinoid receptors antagonists/inverse agonists such as SR141716 (SR1 for $\mathrm{CB}_{1}$ receptor) and SR144528 (SR2 for $\mathrm{CB}_{2}$ receptor) at $1 \mu \mathrm{M}$ could not prevent the CBD-mediated attenuation of TNF- $\alpha$-induced adhesion molecules expression. Results are mean \pm SEM of $n=4-6 /$ group. $* \mathrm{P}<0.05$ vs. vehicle; $\# \mathrm{P}<0.05$ vs. TNF- $\alpha$. 

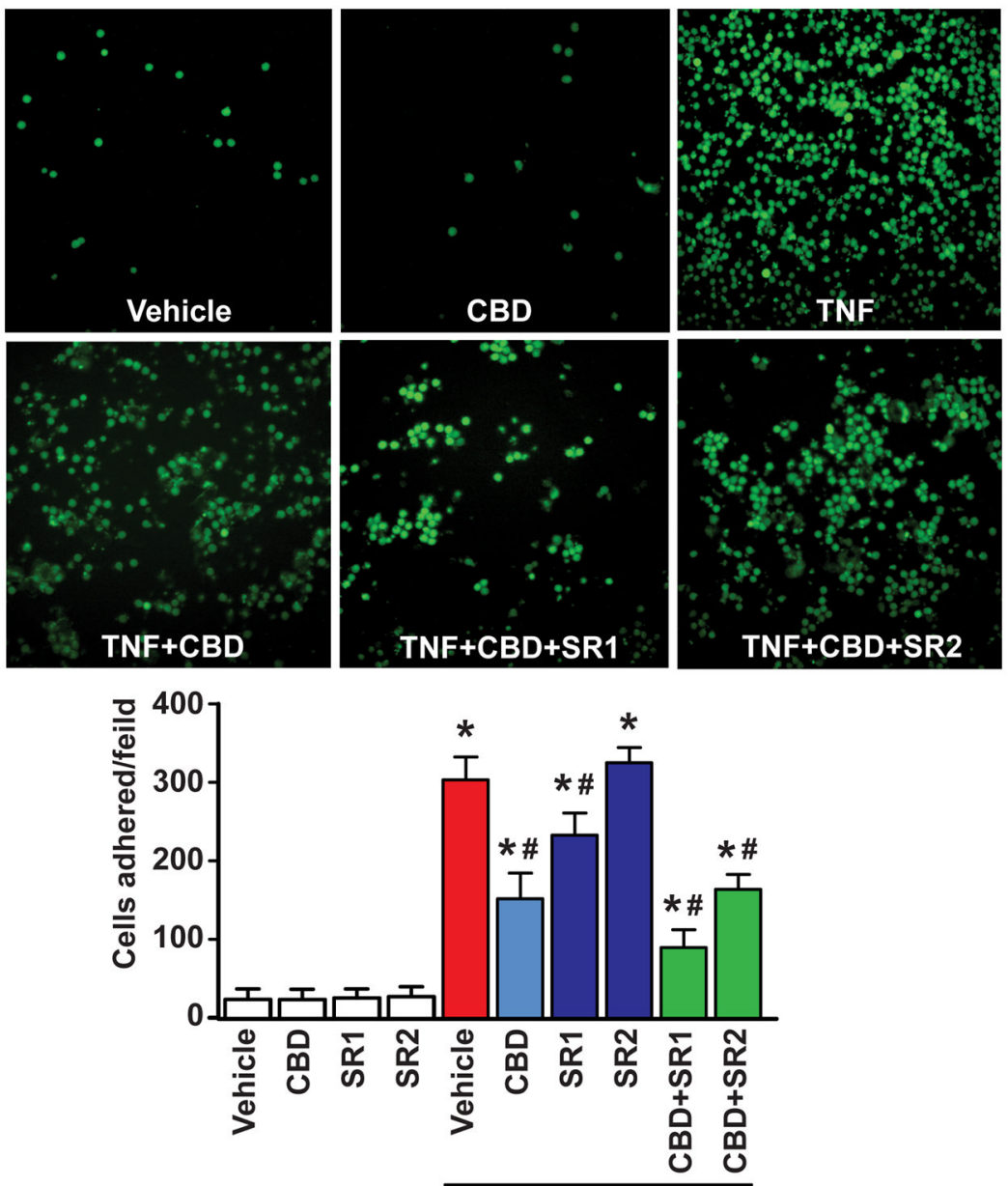

TNF $\alpha 50 \mathrm{ng} / \mathrm{ml}$

Figure 14. Cannabidiol attenuates the TNF- $\alpha$ induced polymorphonuclear cells (PMN) adhesion to human liver sinusoidal endothelial cells (HLSEC)

Representative images and quantification of human neutrophil adhesion to activated human liver endothelial cells. Treatment of HLSEC cells with TNF- $\alpha(50 \mathrm{ng} / \mathrm{ml})$ for $6 \mathrm{hrs}$ markedly enhances PMN adhesion. CBD $(1 \mu \mathrm{M})$ attenuates this enhanced PMN adhesion. Cannabinoid receptors antagonists/inverse agonists such as SR141716 (SR1 for CB 1 receptor) and SR144528 (SR2 for $\mathrm{CB}_{2}$ receptor) at $1 \mu \mathrm{M}$ could not prevent the CBDmediated attenuation of TNF- $\alpha$-induced PMN adhesion. Results are mean \pm SEM of $n=4-6$ / group. $* \mathrm{P}<0.05$ vs. vehicle; $\# \mathrm{P}<0.05$ vs. TNF- $\alpha$. 